OPEN ACCESS

Edited by:

Muhammad Wajid Ullah, Huazhong University of Science and

Technology, China

Reviewed by:

Fida Hussain,

Wuhan Technology and Business

University, China

Fazli Subhan,

National University of Medical

Sciences (NUMS), Pakistan

*Correspondence:

Rui Xie

xierui1511@163.com

Yuqiang Tao

taoyuqiang@usc.edu.cn

${ }^{\dagger}$ The author share first authorship.

Specialty section: This article was submitted to Biomaterials,

a section of the journal Frontiers in Bioengineering and

Biotechnology

Received: 29 June 2021 Accepted: 24 September 2021 Published: 18 November 2021

Citation:

Wang C, Bai J, Tian P, Xie R, Duan Z, Lv Q and Tao Y (2021) The Application Status of Nanoscale Cellulose-Based Hydrogels in Tissue Engineering and

Regenerative Biomedicine.

Front. Bioeng. Biotechnol. 9:732513.

doi: 10.3389/fbioe.2021.732513

\section{The Application Status of Nanoscale Cellulose-Based Hydrogels in Tissue Engineering and Regenerative Biomedicine}

\author{
Chenyang Wang ${ }^{1}$, Jin Bai ${ }^{1+}$, Pei Tian ${ }^{1}$, Rui Xie ${ }^{1 *}$, Zifan Duan ${ }^{1}$, Qinqin $L v^{2}$ and Yuqiang Tao ${ }^{1 *}$ \\ ${ }^{1}$ School of Chemistry and Chemical Engineering, University of South China, Hengyang, China, ${ }^{2}$ The Fourth College of Clinical \\ Medicine, Zhejiang Chinese Medical University, Hangzhou, China
}

As a renewable, biodegradable, and non-toxic material with moderate mechanical and thermal properties, nanocellulose-based hydrogels are receiving immense consideration for various biomedical applications. With the unique properties of excellent skeletal structure (hydrophilic functional groups) and micro-nano size (small size effect), nanocellulose can maintain the three-dimensional structure of the hydrogel to a large extent, providing mechanical strength while ensuring the moisture content. Owing to its unique features, nanocellulose-based hydrogels have made excellent progress in research and development on tissue engineering, drug carriers, wound dressings, development of synthetic organs, 3D printing, and biosensing. This review provides an overview of the synthesis of different types of nanocellulose, including cellulose nanocrystals, cellulose nanofibers, and bacterial nanocellulose, and describes their unique features. It further provides an updated knowledge of the development of nanocellulose-based functional biomaterials for various biomedical applications. Finally, it discusses the future perspective of nanocellulose-based research for its advanced biomedical applications.

Keywords: nanoscale, cellulose, hydrogel, biomedicine, non-toxic material

\section{INTRODUCTION}

Hydrogels are three-dimensional (3D) network materials consisting of cross-linked hydrophilic polymers. These have high and reversible uptake and release capability for water and other fluids (Shi et al., 2016; Arafiles and Futaki, 2021). Among the different polymer-based hydrogels, nanocellulosebased hydrogels are receiving immense consideration owing to their unique surface chemistry, high water holding capacity, moldability, flexibility, and biocompatibility. The cellulose-based hydrogels are widely used for different biomedical applications such as wound dressings (Sultan et al., 2017; Loh et al., 2018; Mao et al., 2021; Wang et al., 2021), tissue engineering (Boyer et al., 2018; Khan et al., 2021), drug delivery (Plackett et al., 2014; Hujaya et al., 2018; Loh et al., 2018), biosensing (Farooq et al., 2020; Subhedar et al., 2021), additive manufacturing (McCarthy et al., 2019a), food packaging (Atta et al., 2021), and several others (Ullah et al., 2021). Some biomedical applications of nanoscale cellulose hydrogels are summarized in Figure 1.

Hydrogels are broadly prepared by two methods: physical cross-linking and chemical crosslinking. The preparation of cellulose-based hydrogels through physical cross-linking takes advantage of the polyhydroxy nature of cellulose, forming many hydrogen bonding to support the mechanical stability of nanoscale cellulose-based hydrogels and form intertwined molecular chains to stabilize 


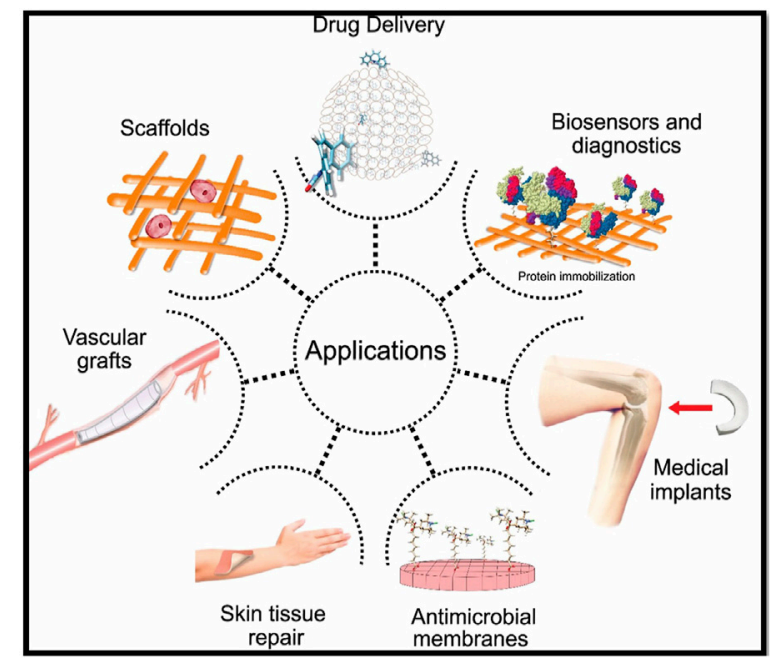

FIGURE 1 | Biomedical applications of nanoscale cellulose hydrogels. Figure reproduced from Toro et al. (2021) under Creative Commons Attribution (CC BY) license.

the 3D structure (Fatima et al., 2021; Ul-Islam et al., 2021). The physical cross-linked cellulose-based hydrogels are widely used in the preparation of biomedical materials because no other chemical substances are added to them, which may otherwise cause toxicity to the cells or tissues, and thus ensuring good biocompatibility without compromising the basic morphology and chemical properties. In contrast, the chemical cross-linked cellulose hydrogels are prepared through a chemical reaction between a compound and cellulose. The chemically crosslinked hydrogels demonstrate high mechanical strength and good elasticity. Moreover, these possess better wear resistance and service life than the physically crosslinked hydrogels.

Cellulose is the most abundant natural polymer on Earth. Its molecular skeleton contains numerous hydrophilic groups such as hydroxyl, aldehyde, and carboxyl groups. Its hydrophilic nature allows the formation of intra and inter-molecular hydrogen bonding, which imparts stability to its structure (France et al., 2017; Hujaya et al., 2018). Furthermore, its high aspect ratio and surface area allow its interaction with other materials of different nature such as polymers, nanoparticles, clays, and others (Shah et al., 2013; Khan et al., 2015a; Ullah et al., 2016a; Sajjad et al., 2019). Its high elastic modulus, high degree of surface functionalization, low density, good biocompatibility, and other properties of nanocellulose make it a material of choice for developing a variety of composite materials for different applications. Different types of nanocellulose not only serve as the matrix but also serve as the fillers or modifiers and enhance the morphological, mechanical, and thermal properties of the host materials.

In general, there are three classes of nanocellulose: cellulose nanocrystals (CNCs), cellulose nanofibers (CNFs), and bacterial nanocellulose (BNC). Among them, CNCs have become an excellent choice for surface modification and doping due to their high purity and high crystallinity, which can provide a rich composite space for the research and development of characteristic hydrogels when applied to the preparation of hydrogels. Similarly, CNFs due to their high degree of polymerization, high water absorption capacity, and high flexibility, can impart high mechanical strength tensile elasticity to hydrogels. Compared to CNCs and CNFs, the $\mathrm{BNC}$ has become the preferred material for the preparation of hydrogels due to its unique fibrous and network morphology similar to natural extracellular matrix (ECM), non-toxicity, biodegradability, high mechanical strength, flexibility, and moldability. The presence of rich intra and inter-molecular and intra-molecular hydrogen bonding stabilizes its structure which in turn enhances the mechanical strength of nanocellulosebased hydrogels (Yang et al., 2014). Due to its ability to main a dynamic balance of water content under the adjustment of osmotic pressure, BNC-based hydrogels are widely used in wound dressing where these prevent the pain and scarring when removing the wound dressing after recovery of wounds or when changing the bandage (Arfin, 2020).

This review provides a comprehensive overview of the preparation, properties, and biomedical applications of different types of nanocellulose-based hydrogels. In comparison to other reviews which mainly summarize the preparation of different types of nanocellulose and their biomedical applications, this review specifically focusses on the preparation of nanocellulose-based hydrogels, highlights the important features of nanocellulose as hydrogels and describes their structure-functional relationship, and finally summarizes the recent trends of applications in tissue engineering and regenerative medicine. We also discussed some future research directions for potential perspectives biomedical applications of nanocellulose.

\section{TYPES OF NANOCELLULOSE AND SYNTHESIS}

The three main classes of nanocellulose, CNCs, CNFs, and BNC, are differentiated from each other in terms of their synthesis method, morphology, and other properties. The following sections describe the synthesis of different types of nanocellulose and their characteristic properties. Table 1 provides a comparative analysis of the synthesis, morphology, dimension, and properties of different types of nanocellulose, while the synthesis of different types of nanocellulose is illustrated in Figure 2.

\section{Cellulose Nanocrystals}

Cellulose nanocrystals or cellulose nanowhiskers are obtained from the amorphous sections of the wood pulp through acid hydrolysis (Trache et al., 2017). Acid hydrolysis is a two-step process: In the first step, alkaline treatment of wood pulp is carried out for the removal of polysaccharides at the fibril surface. In the second step, heat treatment in an acidic environment is carried out for cleaving and destructing the accessible amorphous regions of cellulose fibers. This usually involves the degradation of the amorphous region of cellulose to obtain a suspension of CNCs 
TABLE 1 | A comparative analysis of synthesis, morphology, dimension, and properties of different types of nanocellulose.

\begin{tabular}{|c|c|c|c|c|}
\hline Cellulose type & Synthesis method & Morphology and dimension & Properties & Reference \\
\hline $\begin{array}{l}\text { Cellulose } \\
\text { nanocrystals }\end{array}$ & Acid hydrolysis & $\begin{array}{l}\text { Rod/needle-shaped } \\
\text { Length 150-300 nm }\end{array}$ & $\begin{array}{l}\text { High surface area }\left(400-700 \mathrm{~m}^{2} / \mathrm{g}\right) \text {, } \\
\text { high tensile strength }(7,500 \mathrm{MPa}) \text {, } \\
\text { high stiffness }(\mathrm{E}>140 \mathrm{GPa}) \text {, and } \\
\text { high aspect ratio }(\sim 72), \text { cellulose-I } \\
\text { polymorphic structure }\end{array}$ & $\begin{array}{l}\text { (France et al., 2017; } \\
\text { Grishkewich et al., 2017; SD } \\
\text { et al., 2019; Arfin, 2020) }\end{array}$ \\
\hline $\begin{array}{l}\text { Cellulose } \\
\text { nanofibers }\end{array}$ & $\begin{array}{l}\text { Physical shearing and } \\
\text { homogenization }\end{array}$ & $\begin{array}{l}\text { Mixture of amorphous and crystalline } \\
\text { cellulose chains, } 10-50 \mathrm{~nm} \text { in } \\
\text { diameter and } 500-1,500 \mathrm{~nm} \text { in } \\
\text { length }\end{array}$ & $\begin{array}{l}\text { High surface area }\left(100 \mathrm{~m}^{2} / \mathrm{g}\right) \text {, high } \\
\text { aspect ratio }(\sim 100) \text {, great stiffness ( } \mathrm{E} \\
>100 \mathrm{GPa}), \text { moderate crystallinity } \\
\text { (<70\%), cellulose-I polymorphic } \\
\text { structure }\end{array}$ & $\begin{array}{l}\text { (Nechyporchuk et al., 2016; } \\
\text { Nascimento et al., 2018; } \\
\text { Mohammad et al., 2020) }\end{array}$ \\
\hline $\begin{array}{l}\text { TEMPO-oxidized } \\
\text { cellulose } \\
\text { nanofibers }\end{array}$ & $\begin{array}{l}\text { TEMPO }(2,2,6,6- \\
\text { tetramethylpiperidine-1-oxyl } \\
\text { radical)-mediated oxidation }\end{array}$ & $\begin{array}{l}\text { Nanofibers of } 3-4 \mathrm{~nm} \text { diameter a few } \\
\text { microns in length }\end{array}$ & $\begin{array}{l}\text { Aspect ratios }>100 \text {, cellulose-I } \\
\text { polymorphic structure }\end{array}$ & Isogai and Bergström, (2018) \\
\hline $\begin{array}{l}\text { Bacterial } \\
\text { nanocellulose }\end{array}$ & $\begin{array}{l}\text { In-vivo synthesis in bacterial cells } \\
\text { and extracellular organization into } \\
\text { highly-ordered structures }\end{array}$ & $\begin{array}{l}\text { Fiber diameter (5-10 nm), fiber length } \\
\text { (70-80 nm), particle length (>1 } \mu \mathrm{m}) \text {, } \\
\text { particle width }(30-50 \mathrm{~nm}) \text {, particle } \\
\text { height }(6-10 \mathrm{~nm})\end{array}$ & $\begin{array}{l}\text { High purity, high density }\left(1.5 \mathrm{~cm}^{-3}\right) \text {, } \\
\text { high crystallinity }(65-90 \%), \text { high } \\
\text { degree of polymerization } \\
\text { (800-10,000), high surface area } \\
\text { (24-40), highly porous, cellulose-I } \\
\text { polymorphic structure }\end{array}$ & $\begin{array}{l}\text { (Klemm et al., 2005; Ul-Islam } \\
\text { et al., 2012, 2019a; Mishra } \\
\text { et al., 2018; Ullah et al., 2019b) }\end{array}$ \\
\hline $\begin{array}{l}\text { Cell-free } \\
\text { nanocellulose }\end{array}$ & In-vitro cell-free enzyme system & $\begin{array}{l}\text { Nanofibers of } 85-98 \mathrm{~nm} \text { diameter } \\
\text { and few microns in length }\end{array}$ & $\begin{array}{l}\text { High water holding capacity } \\
\text { (188.6 times of dry weight), high } \\
\text { tensile strength ( } 17.63 \mathrm{MPa}) \text {, high } \\
\text { thermal stability, cellulose-II } \\
\text { polymorphic structure }\end{array}$ & $\begin{array}{l}\text { (Ullah et al., 2015, 2017; Kim } \\
\text { et al., 2019) }\end{array}$ \\
\hline
\end{tabular}

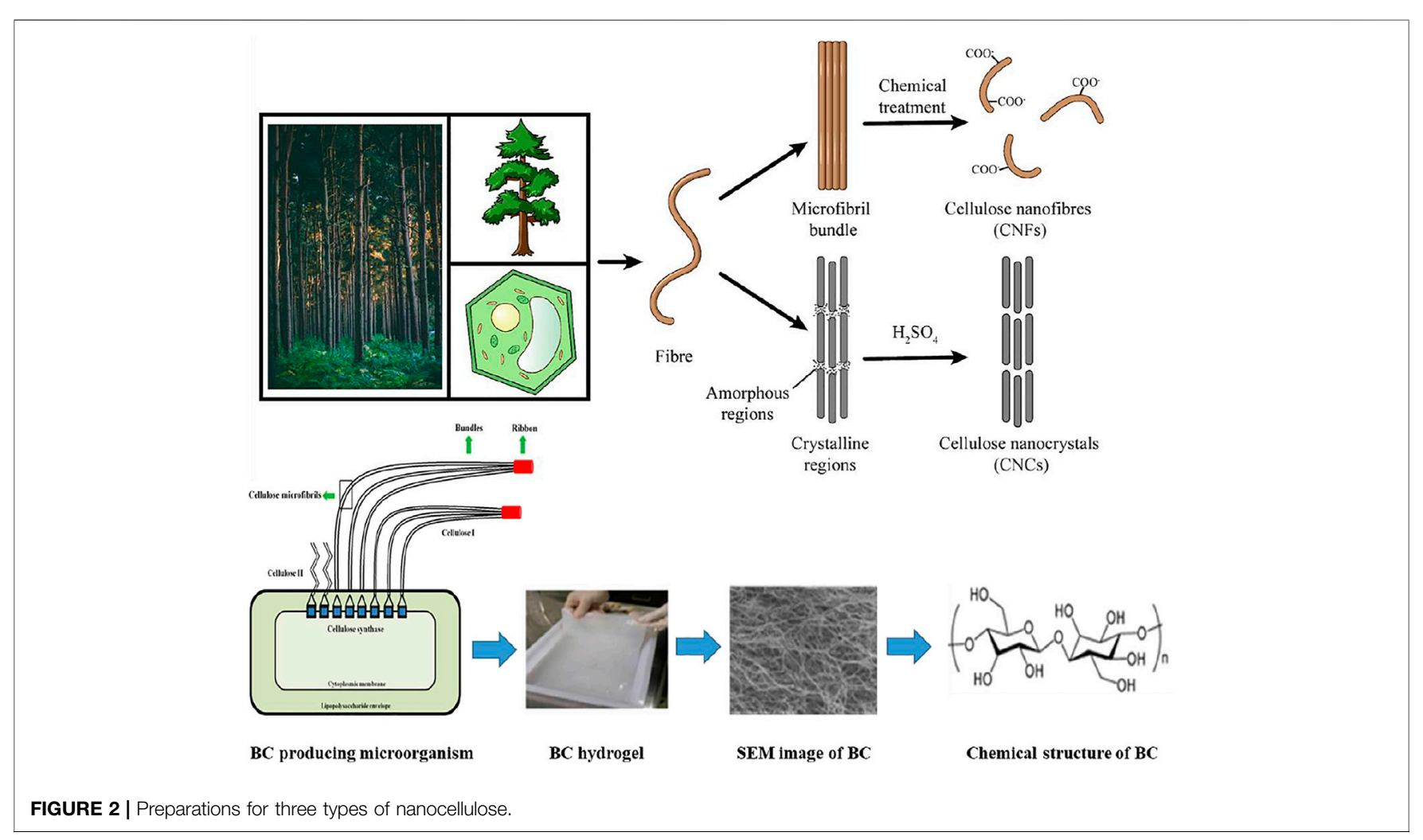

with high crystallinity. CNCs appear as rod or needle-like structures under scanning or transmission electron microscope. The structural and morphological features of
CNCs are greatly dependent on the raw material, type of acid, reaction temperature and time, and intensity of ultrasonic irradiation (Chen et al., 2009). For example, changing the 
cellulose source from cotton fibers to ascidian produced CNCs of diameter 200-300 $\mathrm{nm}$ and $>1 \mu \mathrm{m}$, respectively, under the same experimental conditions (Heux et al., 2000; Pakzad et al., 2012). The degree of hydrolysis of cellulose by inorganic acid is not only related to acid concentration but also related to the temperature. With the increase of hydrolysis temperature, the crystallinity of fiber first increases and then decreases, and there is a maximum value. The possible reason is that the aggregation ability of fiber increases with the increasing temperature and result in the decrease of crystallinity. A recent study reported the optimum parameters for sulfuric acid hydrolysis with acid hydrolysis time of $60 \mathrm{~min}$, hydrolysis temperature of $45^{\circ} \mathrm{C}$, sulfuric acid concentration of $64 \%$, ultrasonic wave treatment for $30 \mathrm{~min}$. Under such treatment, CNCs with a particle size of $18-26 \mathrm{~nm}$ were obtained (Tuerxun et al., 2019). In addition to acid hydrolysis, CNCs could also be obtained by treating the lignocellulosic material with reagents like tetramethylpiperidine-1-oxyl (TEMPO) (Saito et al., 2007), ammonium persulfate (APS) (Wågberg et al., 2008), and some bio-based enzymes (Pääkko et al., 2007). Similarly, TEMPO-oxidized CNCs could be obtained by treating the lignocellulosic material with TEMPO, $\mathrm{NaBr}$, and $\mathrm{NaClO}$ in an alkaline environment (Saito et al., 2007). Besides, CNCs could also be obtained through enzymatic hydrolysis of microcrystalline cellulose (Satyamurthy et al., 2011); however, this method is not feasible due to the high cost of enzymes.

\section{Cellulose Nanofibers}

Cellulose nanofibers are obtained through grinding, homogenization, and ultrasonication of wood, cotton, fibers, and tunicate, etc. Among these methods, homogenization is commonly used; however, the traditional high-pressure homogenization has a long working cycle, low yield, and is easy to be blocked by cellulose. Besides, CNFs are also produced chemically, such as through oxidation of raw material by TEMPO under magnetic stirring (Saito et al., 2007). Sometimes, both physical and chemical processes are used together for the preparation of CNFs. For example, carboxymethylation and high-pressure homogenization produce uniformly distributed CNFs (Wågberg et al., 2008). The CNFs hydrogels are prepared through mechanical treatment of their aqueous suspension with alkali and neutralization (Abe and Yano, 2011, 2012). CNFs contain both amorphous and crystalline regions and are long and flexible interconnected fibrils. Similar to CNCs, their length and diameter also vary according to the type of source material. In general, CNFs vary in the diameter of $10-50 \mathrm{~nm}$ and length of 500-1,500 nm (Chen W. et al., 2018). These possess properties like high aspect ratio and surface area, high mechanical strength and crystallinity, and pre-colation threshold.

\section{Bacterial Nanocellulose}

Bacterial nanocellulose is produced by a special class of acetic acid bacteria as well as by the cell-free enzyme systems. Compared to CNCs and CNFs, BNC represents the purest form of cellulose as it does not contain ingredients like hemicellulose, lignin, and minerals. The biosynthesis of BNC by these two systems is a chemical process mediated by specific enzymes. It possesses superior structural, physico-chemical, mechanical, and biological properties (Ul-Islam et al., 2019a). It is synthesized intracellularly by the microbial cells in the form of $\beta$-1,4-glucan chains. The chains are extruded to the external medium as protofibrils through the terminal complexes (TCs). The TCs are present in the outer cellular membrane. The excreted fibrils crystallize and form the ribbon-shaped microfibrils, which then form pellicles. The pellicles grow in size at the top of the air-medium interface. The pellicles are comprised of bundles, which then form the ribbon. The cellulose synthesis by microbial cells and cell-free enzyme system differs at the excretion step as the latter does not possess the external membrane barrier. Furthermore, the microbial cells produce cellulose I, while the cell-free enzyme system produces cellulose II polymorphic form (Ullah et al., 2016b; Kim et al., 2019).

\section{BIOMEDICAL APPLICATION OF NANOCELLULOSE}

Different types of nanocellulose are receiving immense consideration for a range of applications in different fields, with particular attention received in the biomedical sector. The following sections overview the trends of biomedical applications of nanocellulose.

\section{Tissue Engineering Hydrogels and Scaffolds}

Tissue engineering refers to the utilization of principles and methods of engineering and life science to fundamentally understand the structure-function relationship between the normal and diseases tissues with the aim to develop biological substitutes of damaged or lost organs and tissues and for restoring their lost function (Aljohani et al., 2018). Over the last few decades, this field has received immense consideration in biomedical research, and the potential of different materials has been widely explored to make scaffolds mimicking the natural tissues and organs. The tissue engineering scaffolds support the growth of cells by providing an appropriate environment for their adhesion, proliferation, and differentiation by providing nutrients and growth factors and allowing the exchange of metabolites and gases (Halib et al., 2019). Moreover, such scaffolds demonstrate features such as biocompatibility, non-toxicity, biodegradability, mechanical strength, plasticity, porosity, and others, which are modulated in the desired way by using the different combinations of natural and synthetic materials to meet the pre-requisites of the target tissue or organ (Moroni et al., 2014; Tummala, et al., 2019).

Nanocellulose is considered an ideal material for the development of tissue engineering scaffold because of its renewability, biocompatibility, biodegradability, non-toxicity, rheological properties, and high mechanical strength (Lin and Dufresne, 2014). Over the last couple of decades, the hydrogels based on CNFs, CNCs, and BNC have been widely used in tissue 


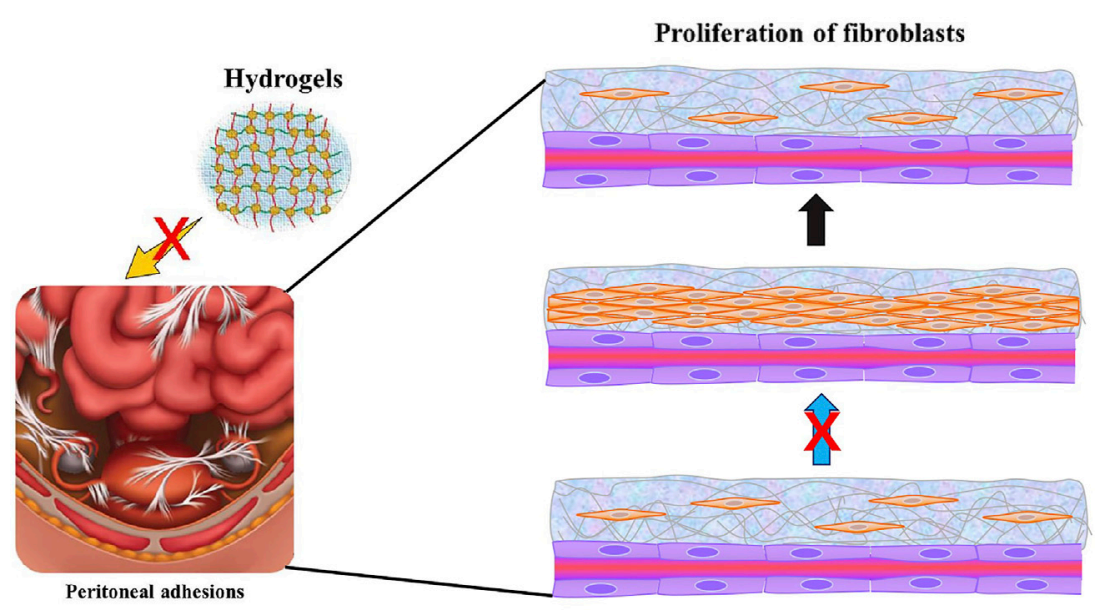

FIGURE 3 | Schematic diagram of injectable anti-adhesion hydrogel.

TABLE 2 | The improved properties and targets of different nanocellulose-based tissue engineering scaffolds.

\begin{tabular}{|c|c|c|c|c|c|}
\hline $\begin{array}{l}\text { Cellulose } \\
\text { type }\end{array}$ & $\begin{array}{l}\text { Reinforcement } \\
\text { material }\end{array}$ & $\begin{array}{l}\text { Synthetic } \\
\text { strategy }\end{array}$ & $\begin{array}{l}\text { Improved/Added } \\
\text { properties }\end{array}$ & Applications & References \\
\hline \multirow[t]{13}{*}{$\mathrm{BNC}$} & $\begin{array}{l}\text { Polypyrrole and carbon } \\
\text { nanotubes }\end{array}$ & Regeneration & $\begin{array}{l}\text { Thermal stability, mechanical strength, } \\
\text { recoverability, swelling ability, electrical } \\
\text { conductivity, cytocompatibility }\end{array}$ & Tissue engineering & Wang et al. (2020b) \\
\hline & $\kappa$-carrageenan & In-situ & $\begin{array}{l}\text { Mechanical strength, water uptake and retention, } \\
\text { swelling, cell viability, and gene expression }\end{array}$ & Tissue engineering & Cielecka et al. (2018) \\
\hline & Collagen & In-situ & $\begin{array}{l}\text { Thermal stability, mechanical strength, } \\
\text { cytocompatibility }\end{array}$ & $\begin{array}{l}\text { Wound dressing and } \\
\text { tissue engineering }\end{array}$ & $\begin{array}{l}\text { Zhijiang and Guang, } \\
\text { (2011) }\end{array}$ \\
\hline & Montmorillonite & Ex-situ & $\begin{array}{l}\text { Antibacterial activity, water release rate, } \\
\text { biocompatibility, and wound healing }\end{array}$ & Biomedical & $\begin{array}{l}\text { (Ul-Islam et al., 2013; } \\
\text { Sajjad et al., 2019) }\end{array}$ \\
\hline & Chitosan & Ex-situ & $\begin{array}{l}\text { Mechanical strength, water holding capacity and } \\
\text { release rate, Cytocompatibility, 3D growth pattern, } \\
\text { cell-scaffold interaction }\end{array}$ & $\begin{array}{l}\text { Diagnosis of ovarian } \\
\text { cancer }\end{array}$ & Ul-Islam et al. (2019b) \\
\hline & Xyloglucan & - & Enhanced mechanical properties, biocompatible & $\begin{array}{l}\text { Characterize and design } \\
\text { biomaterial }\end{array}$ & Bonilla et al. (2016) \\
\hline & - & - & Stripe ordered BC & $\begin{array}{l}\text { Scaffolds for nerve, } \\
\text { skeleton, and hamstring }\end{array}$ & Zang et al. (2014) \\
\hline & Reduced graphene oxide & - & Biocompatible, conductive, hydrophilic & $\begin{array}{l}\text { Bioelectronics, tissue } \\
\text { engineering }\end{array}$ & Kang et al. (2016) \\
\hline & $\mathrm{NaCl}$ & Regeneration & Porous & Tissue engineering & Khan et al. (2015b) \\
\hline & CNC and protein & - & Biocompatible & Bone tissue engineering & Zhang et al. (2019) \\
\hline & Graphene oxide & - & High tensile strength and biocompatible & Tissue engineering & Si et al. (2014) \\
\hline & $\begin{array}{l}\text { Hydroxyapatite and } \\
\text { carboxymethyl cellulose }\end{array}$ & Ex-situ & Crystallinity, thermal stability, cytocompatibility & Biocompatibility & Grande et al. (2009) \\
\hline & Zinc oxide nanoparticles & Regeneration & $\begin{array}{l}\text { Thermal stability, mechanical strength, antibacterial } \\
\text { activity, cytocompatibility }\end{array}$ & $\begin{array}{l}\text { Biomedical, } \\
\text { bioelectroanalysis }\end{array}$ & Ul-Islam et al. (2014) \\
\hline \multirow[t]{4}{*}{ CNCs } & PEGDA & 3D printing & Mechanical, thermal, and biological properties & Tissue scaffold & NB et al. (2017) \\
\hline & PVA & Freeze-thaw cycle & Stability, dispersion, and mechanical strength & Tissue scaffold & $\begin{array}{l}\text { Shoda and Sugano, } \\
\text { (2005) }\end{array}$ \\
\hline & PVA & $\begin{array}{l}\text { Low-temperature } \\
\text { crosslinking }\end{array}$ & Biocompatibility and mechanical strength & Tissue scaffold & Tummala et al. (2019) \\
\hline & CNF, alginate & Ex-situ & Controlled pore size, biocompatible & Tissue engineering & Al-Sabah et al. (2019) \\
\hline \multirow[t]{3}{*}{ CNF } & Hydroxyapatite & Ex-situ & $\begin{array}{l}\text { Extra ordinary mechanical properties, } \\
\text { biocompatible }\end{array}$ & Bone tissue engineering & Ao et al. (2017) \\
\hline & Alginate & $\begin{array}{l}\text { 3D extrusion } \\
\text { printing }\end{array}$ & 3D structure, biocompatible & Cartilage regeneration & $\begin{array}{l}\text { Markstedt et al. } \\
\text { (2015) }\end{array}$ \\
\hline & Alginate & 3D printing & $\begin{array}{l}\text { Porosity, mechanical strength, crosslinking, } \\
\text { biocompatibility }\end{array}$ & Tissue scaffold & Abouzeid et al. (2018) \\
\hline
\end{tabular}


engineering due to their highly hydrated porous 3D structure and excellent mechanical properties. Moreover, its gel-like and flexible 3D porous structure supports the adhesion and growth of cells and replicates the niche found in vivo (Curvello et al., 2019). The porous and 3D fibrous structure of BNC allows the gaseous and nutrients exchange. Most importantly, the nanocellulose-based hydrogels have structural similarity with the ECM enabling them to support the proliferation and differentiation of cells and thus making it a useful material for in vitro and in vivo applications. In a study, Sultana et al. developed heat-responsive TEMPO-oxidized nanocellulose (TOCN) injectable hydrogels for relieving the post-surgical peritoneal adhesion after surgery. The prepared physical barrier remains in a liquid state at low temperature $\left(4^{\circ} \mathrm{C}\right)$ and self-transformed into gel at near human body temperature $\left(37^{\circ} \mathrm{C}\right)$ in merely $45 \mathrm{~s}$. After 14 days of experimental culture in vitro, the survival rates of $0.2 \%$ TOCN hydrogel on rat bone marrow mesenchymal stem cells (RBMSCs) and L929 fibroblast models were 89.24 and $91.25 \%$, respectively, indicating the non-toxic nature of the developed hydrogel. In the rate cecal wall abrasion model, the developed hydrogel showed a good anti-peritoneal adhesion effect and effectively reduced the proliferation of fibroblasts. The developed hydrogel system effectively reduced post-surgery tissue adhesion. The injected TOCN hydrogel as a sol-gel barrier can be used under laparoscope and thus could potentially avoid the second surgery after injury (Sultana et al., 2019). The nanocellulose-based hydrogel system can be a costeffective and efficient substitute for commercial hydrogels owing to the renewability, biocompatibility, and biodegradability of nanocellulose. The development and application of heatsensitive nanocellulose-based injectable hydrogel are illustrated in Figure 3. Furthermore, Table 2 summarizes the development of different nanocellulose-based scaffolds with a variety of materials for different tissue engineering applications.

\section{Wound Dressing and Healing}

Skin is the largest organ in the human body. It covers the vital organs of the body and serves as a physical and chemical barrier and protective layer against environmental hazards. Skin performs important functions such as detecting sensation, controlling body temperature, regulating the exchange of water and electrolytes, and preventing harmful substances from invading the human body. As the most significant barrier of the human body, skin is often vulnerable to injuries such as hightemperature scald, low-temperature frostbite, mechanical trauma, microbial contamination, and so on (Metcalfe and Ferguson, 2007). Such injuries often lead to the development of wounds at the injury or infection site. If the wound is not healed in time, it may lead to inflammation and other pathological changes. Therefore, to avoid damage to the skin and underlying organs, which could affect the function and cause secondary injuries, it is necessary to treat the wounds effectively and quickly to heal the wounds. One effective approach is to apply wound dressing materials to facilitate the repair process of damaged skin. Wound dressing is an effective method for rapid recovery and treatment of injured tissues. An effective wound dressing material should promote the proliferation and differentiation of wound cells by constructing physical barriers. The materials used as wound dressing should meet the certain criterion: no biological toxicity, no sensitization, good gas permeability, absorption of wound exudates, antimicrobial activity, anti-inflammation, easy removal, and no secondary injury to the wound site (Di et al., 2017).

The nanocellulose-hydrogel could be an ideal choice as a wound dressing material because it meets the properties of effective wound dressing materials such as biocompatibility, non-toxicity, and biodegradability (Boateng et al., 2008). The high water content of nanocellulose-based hydrogels provides a humid environment for wounds, while its highly porous and fibrous structure allows gaseous and nutrients exchange. Nanocellulose hydrogels can effectively absorb wound exudates. Among the different types of nanocellulose, the 3D fibrous network of BNC is similar to ECM, thus providing an ideal environment for cell growth and tissue repair. In a study, Loh et al. developed a hydrogel cell carrier based on BNC and acrylic acid BC/AA and utilized it for full-thickness wound healing treatment. The BC/AA composite hydrogel supported the adhesion and growth of human epidermal keratinocytes (EK) and dermal fibroblasts (DF) and quickly transferred the cells from hydrogel to wound. The visual observation, histological analysis, immunohistochemical staining, and transmission electron microscope (TEM) showed good wound closure in the animal model (Loh et al., 2018). In a recent study, Sajjad et al. developed a nanocomposite of $\mathrm{BCN}$ and curcumin nanoparticles. The $\mathrm{BC} /$ curcumin nanocomposite was utilized as a wound dressing hydrogel that effectively healed the burn wounds in the rat model (Sajjad et al., 2020). A typical wound healing in the skin by using nanocellulose-based hydrogel is demonstrated in Figure 4. In another study, Basu et al. developed calcium crosslinked nanocellulose (NFCs) hydrogel for use as wound dressing material. They developed cation NFC (c-NFC) and carboxylated NFC (a-NFC) hydrogel by modifying the CNFs, and the selfstable c-NFC hydrogel was prepared by adding calcium ions to c-NFC. Similarly, the AC-NFC hydrogel was prepared by mixing c-NFC and a-NFC suspensions at 2:1 ratio by adding calcium ions. The A-NFC and AC-NFC hydrogels showed good water retention ability and maintained a moist environment, highlighting the potential of the physical and chemical properties of the material to promote wound healing. The developed hydrogels did not affect the growth and proliferation of new skin cells on the wound surface as well as their removal as a dressing material did not damage the repaired skin. In addition, the level of reactive oxygen species remained stable, indicating the inert nature of the developed hydrogels. The biocompatible and non-inflammatory properties of the nanocellulose-based hydrogels to skin cells and monocytes further highlight their potential as the ideal wound dressing materials. Table 3 summarizes the development of different nanocellulose-based scaffolds with a variety of materials for wound dressing applications.

\section{Drug Delivery}

A drug delivery system refers to a mechanism of transporting a drug or a therapeutic agent to the target site to achieve its 

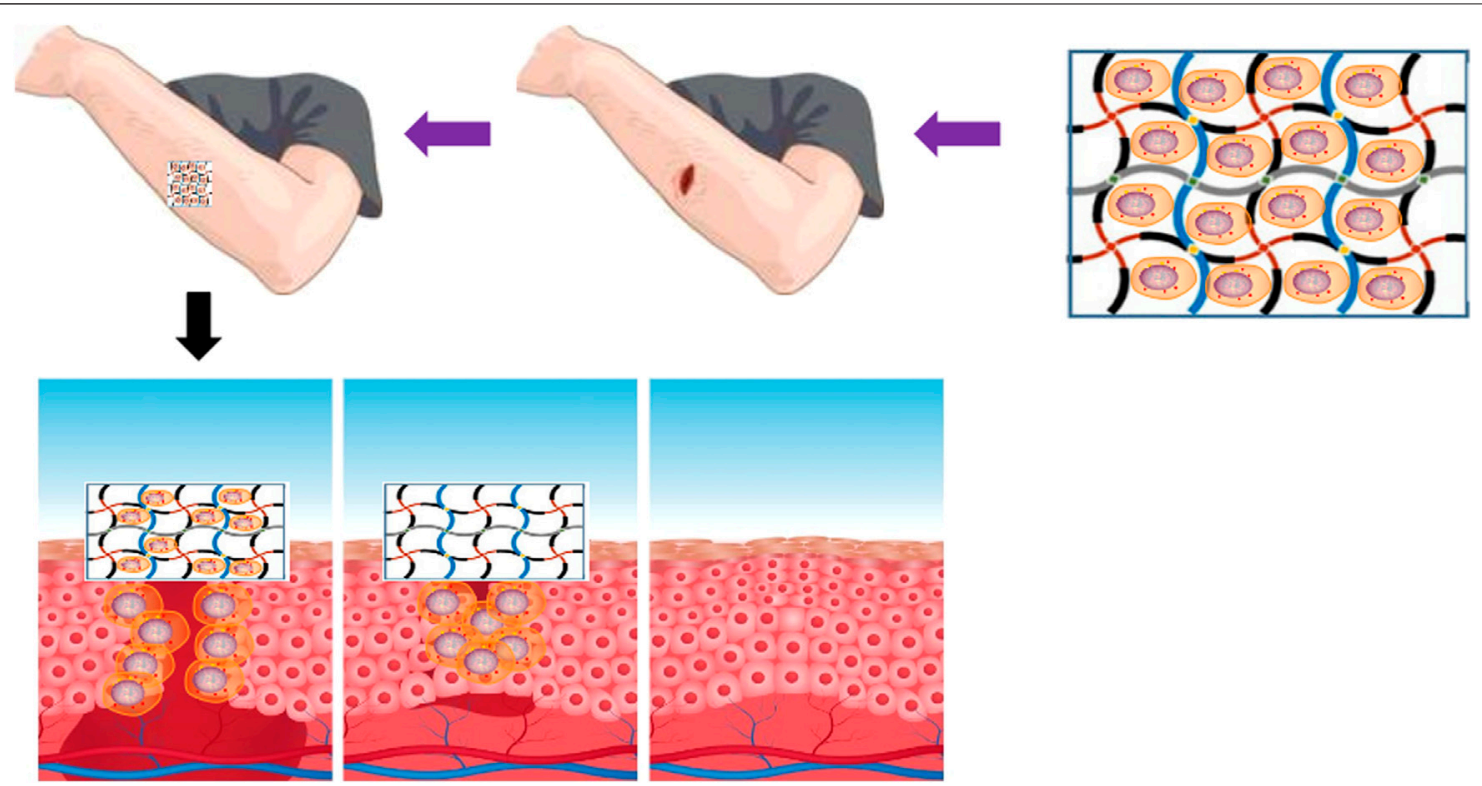

FIGURE 4 | Schematic diagram of wound healing promoting effect of BC hydrogel.

maximum therapeutic effect for treating a disease or illness. In general, drugs are delivered to the target site by using suitable carriers. An ideal carrier used for delivery of drug to the target site must demonstrate some unique features or offer advantages like biocompatibility, low or no toxicity, high drug loading or encapsulation efficiency, targeted and efficient drug transport to the target site, simple preparation, and low production cost, extended in vivo circulation time, and so on (Li et al., 2021). Compared to the traditional drug delivery systems, the hydrogelbased drug delivery systems are less toxic and have minimal side effects (Ribeiro et al., 2014).

For its use in developing drug delivery systems, nanocellulose possesses all important features such as high hydrophilicity, stability, biocompatibility, non-toxicity, appropriate mechanical strength, biodegradability, easy surface modification, and low preparation cost. Furthermore, due to its 3D fibrous network, porosity, and high surface area, nanocellulose-based hydrogels can offer high drug loading capacity while flexibility in its unique surface chemistry allows the controlled release. In a study, Poonguzhali prepared the composite membrane of ampicillin-loaded sodium alginate and $\mathrm{CNC}$ through the solution casting method. The sodium alginate/CNC composite membrane showed the release of ampicillin showed greater drug release compared to the membrane without CNC. The developed composite showed extended drug release for up to $500 \mathrm{~min}$ and demonstrated good swelling behavior in an alkaline medium, indicating that it could be used for extended drug release (Poonguzhali et al., 2018). In another study, Hong et al. carboxymethylated CNF and prepared the ciprofloxacin-montmorillonite (CIPMMT) composite for sustained release of antibiotic drugs. Herein, carboxymethylated cellulose nanofibrils (CMCNF) were used as the carrier. Although montmorillonite can delay the sustained release of drugs, the delay time is only $6-24 \mathrm{~h}$ at most. The CMCNF-CIP-MMT complex drug system was prepared by adding 1.5, 2, and 3\% CMC-CNF into the CIP-MMT system. The in vitro release experiments showed sustained drug release by the CIP-MMT system. The sustained release of CIP for more than $6 \mathrm{~h}$ and the dissolution of the matrix can be delayed by adding CMCNF into the system. The sustained release process of the drug increases with the increase of CMCNF, and the sustained release of 3\% CMCNF-CIP-MMT can last for more than $48 \mathrm{~h}$. The antibacterial experiment showed that the $3 \%$ CMCNF-CIP-MMT composite showed stable antibacterial activity within 12 days (Hong et al., 2019). In another study, Jagadeesen et al. used CNCs extracted from rice husk as raw materials. They further modified the CNCs by imparting magnetic property (m-CNCs) through the co-precipitation method. The m-CNCs were dispersed in alginate-based hydrogel beads, which enhanced the mechanical strength and regulated the drug release behavior. It was found that the existence of $\mathrm{m}$-CNCs not only improved the magnetic properties of alginate hydrogel beads but also enhanced the stability and swelling rate of hydrogel beads. The developed hydrogel showed high loading of ibuprofen and controlled release for extended time period (Supramaniam et al., 2018).

In order to enhance the stability of drug binding and ensure the controlled release of drugs, the nanocellulose-hydrogel drug carrier system can be chemically modified to prepare the stimulus-responsive drug carriers, such as $\mathrm{pH}$, temperature, light, and ultrasonic response (Karimian et al., 2019). The stimuli-responsive hydrogels are used as the drug carrier for constructing drug controlled release system, which could potentially solve the issue of administration of multiple drugs 
TABLE 3 | The improved properties and wound healing applications of different nanocellulose-based composites.

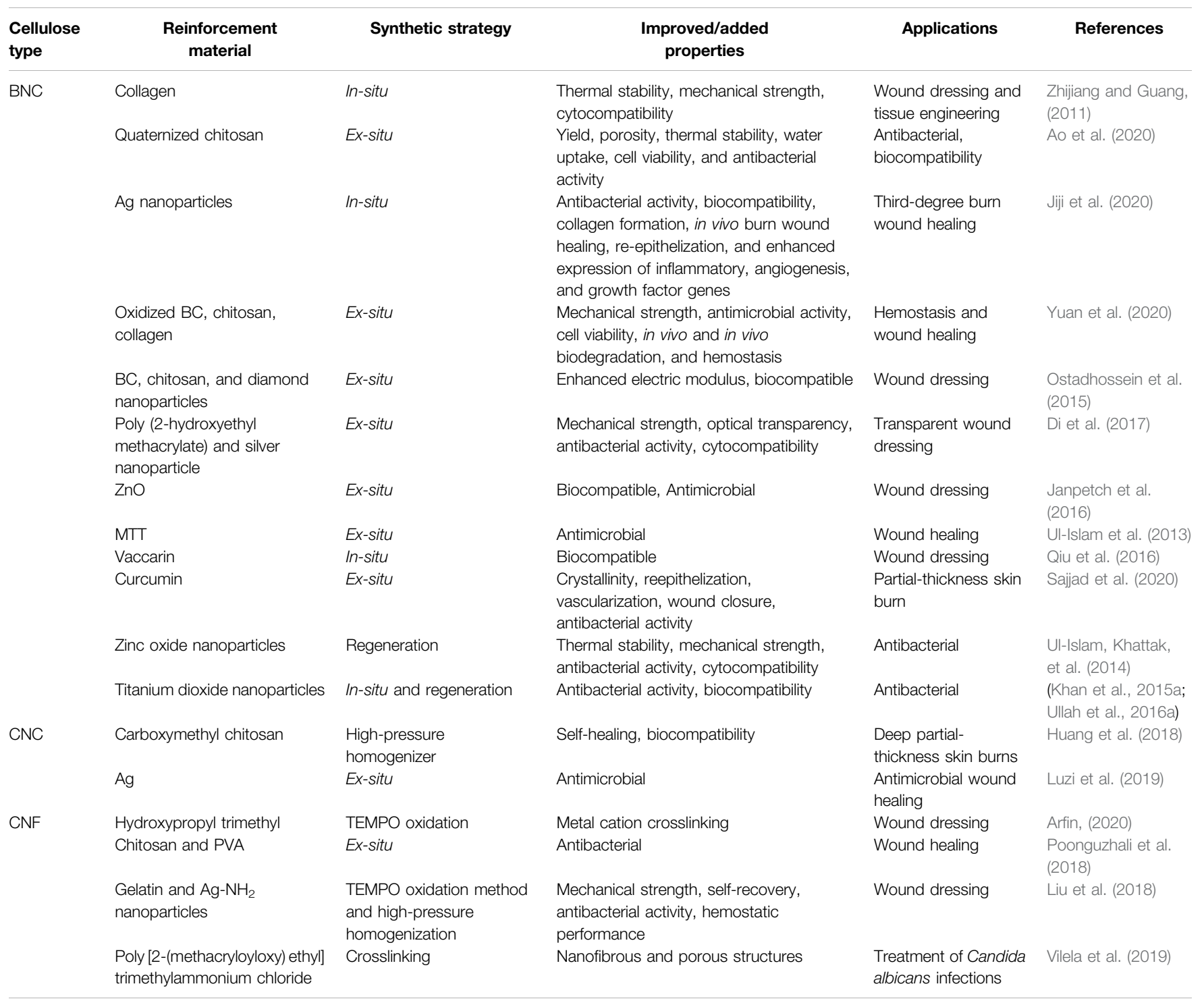

in traditional administration mode. In addition, such hydrogels could reduce the stimulation effect of drugs on the normal cells and ensure controlled and targeted delivery of drugs, which could ultimately lead to the improved therapeutic effect of the drug. In recent years, stimuli-responsive hydrogels based on nanocellulose have received immense consideration. In a study, Li et al. developed a sandwich structure of BNC with polyaniline through chemical oxidation polymerization. Herein, polyaniline was densely arrayed along the cellulose fibers, and a model drug berberine hydrochloride was diffused within the hydrogel matrix. The sandwich structure allowed a controlled release under the effect of varying $\mathrm{pH}$ and electric fields. The system showed fast drug release in an alkaline environment and slow in an acidic environment ( $\mathrm{Li}$ et al., 2018). In another study, Yunessnia et al. developed a CNCs/chitosan nanocomposite hydrogel. With the increasing concentration of chitosan, the isoelectric point and swelling ratio of the composite hydrogel increased. The $\mathrm{CNC} /$ chitosan showed in vitro release of theophylline, where the cumulative drug release at $\mathrm{pH} 1.5$ was significantly higher than at $\mathrm{pH}$ 7.4. A cumulative release of $85 \%$ was achieved at $\mathrm{pH} 1.5$ when $3 \%$ chitosan was used. The findings of this study indicate that the $\mathrm{CNC} /$ chitosan nanocomposite could be used for gastric-specific drug delivery (Yunessnia lehi et al., 2019). In a more detailed study, Liu et al. developed a nanocellulose hydrogel-based drug carrier with multiple response characteristics $(\mathrm{pH}$, nearinfrared light, and long-term slow-release). In-situ growth of nano zinc-based MOF(ZIF-8) was controlled by nano dopamine (PDA) as a template to obtain PDA@ZIF-8 nanocomposites. Then, the drug tetracycline hydrochloride was loaded by PDA@ ZIF-8 nanocomposites, and then the PDA@ZIF-8/TOCNFs composite hydrogel material with drug slow-release function was prepared by calcium ion crosslinking. The results showed a maximum encapsulation efficiency and loading rate of 


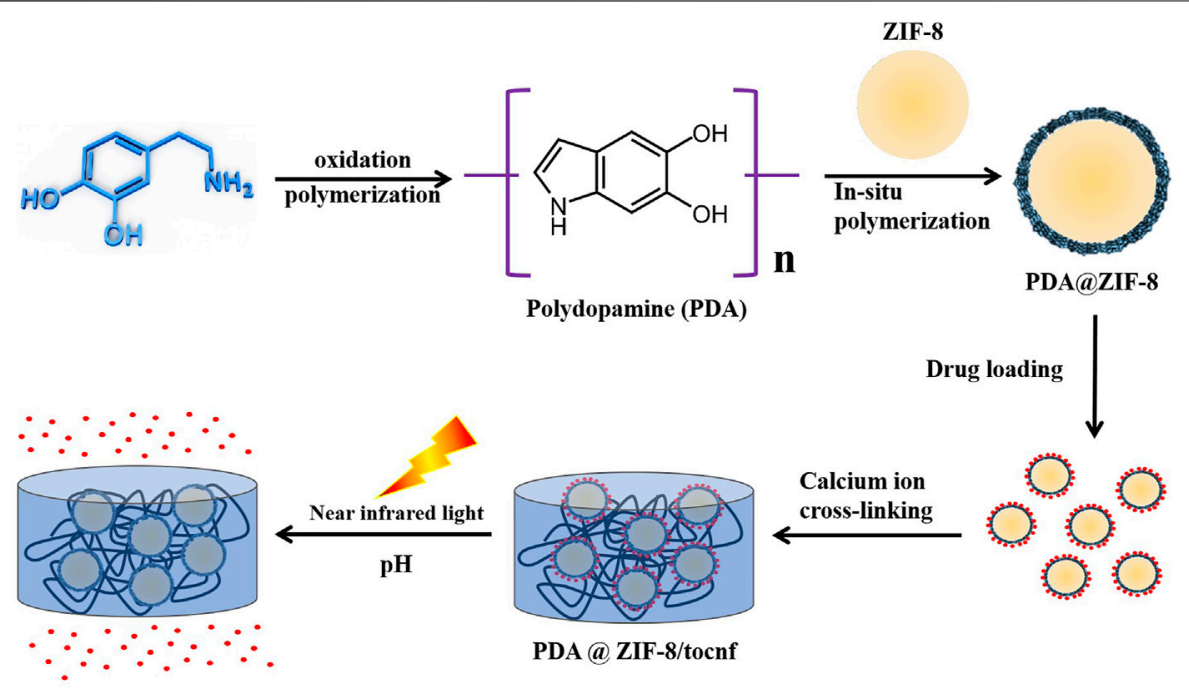

FIGURE $\mathbf{5}$ | Preparation of composite hydrogel and its application in drug delivery.

\begin{tabular}{|c|c|c|c|c|c|}
\hline $\begin{array}{l}\text { Cellulose } \\
\text { type }\end{array}$ & $\begin{array}{l}\text { Reinforcement } \\
\text { material }\end{array}$ & Synthetic strategy & $\begin{array}{l}\text { Improved/added } \\
\text { properties }\end{array}$ & Applications & References \\
\hline \multirow[t]{4}{*}{$\mathrm{BNC}$} & $\begin{array}{l}\text { Graphene oxide and } \\
\text { ibuprofen }\end{array}$ & Ex-situ & $\begin{array}{l}\text { Cell viability, sustained drug release } \\
\text { in vitro }\end{array}$ & Drug delivery & Luo et al. (2017) \\
\hline & $\begin{array}{l}\text { Oxidized BC and } \\
\text { polyethyleneimine }\end{array}$ & Ex-situ & $\begin{array}{l}\text { Adsorption, sustained drug release } \\
\text { in vitro, biocompatibility }\end{array}$ & Drug delivery & Chen et al. (2018b) \\
\hline & Polyaniline & Ex-situ & $\begin{array}{l}\text { pH-responsiveness, electrical } \\
\text { conductivity }\end{array}$ & $\begin{array}{l}\text { Controlled drug } \\
\text { delivery }\end{array}$ & Li et al. (2018) \\
\hline & - & Freeze-drying & $\mathrm{pH}$-dependent release rate, 3D structure & $\begin{array}{l}\text { Controlled drug } \\
\text { delivery }\end{array}$ & Huang et al. (2013) \\
\hline \multirow[t]{4}{*}{ CNCs } & CMC, starch, and pectin & Ex-situ & $\mathrm{pH}$ resistance & Probiotics delivery & $\begin{array}{l}\text { Khorasani and } \\
\text { Shojaosadati, (2017) }\end{array}$ \\
\hline & Chitosan & $\begin{array}{l}\text { Ex-situ TEMPO oxidation } \\
\text { method }\end{array}$ & Ionic crosslinking, extended drug release & Drug delivery & Maestri. et al. (2020) \\
\hline & Chitosan & Ex-situ & pH-sensitivity, high swelling & Drug delivery & (Q et al., 2019) \\
\hline & Alginate & $\begin{array}{l}\text { High-pressure } \\
\text { homogenization }\end{array}$ & Magnetic behavior, high swelling, stability & $\begin{array}{l}\text { Controlled drug } \\
\text { delivery }\end{array}$ & Supramaniam et al. (2018) \\
\hline \multirow[t]{3}{*}{ CNFs } & Chitosan & TEMPO oxidation method & High swelling, crosslinking stability & Drug delivery & (Q et al., 2019) \\
\hline & $\begin{array}{l}\text { Quaternary ammonium salt } \\
\text { group }\end{array}$ & $\begin{array}{l}\text { High-pressure } \\
\text { homogenizer }\end{array}$ & $\begin{array}{l}\text { High swelling, high drug loading, and } \\
\text { controlled release }\end{array}$ & - & Hujaya et al. (2018) \\
\hline & PANIPAM & $\begin{array}{l}\text { Free radical } \\
\text { polymerization }\end{array}$ & $\begin{array}{l}\text { High swelling, compression strength, dual } \\
\text { responsive }\end{array}$ & Drug delivery & Masruchin et al. (2017) \\
\hline
\end{tabular}

tetracycline hydrochloride by PDA@ZIF-8. In addition, PDA@ ZIF-8/TOCNFs composite hydrogel has good $\mathrm{pH}$ and nearinfrared light-sensitive drug release characteristics. In the acidic buffer system, the sustained release time of the drug was as long as $85 \mathrm{~h}$, and the drug release rate was $72 \%$, and there was no abrupt release phenomenon at the initial stage. These results show that the PDA@ZIF-8/TOCNFs composite hydrogel has good drug release characteristics. Furthermore, the PDA@ZIF8/TOCNFs composite hydrogel did not show toxicity to human umbilical vein cells, thus indicating their biocompatible nature (Khamrai et al., 2019). A schematic illustration of the preparation of composite hydrogel and its application in drug delivery is shown in Figure 5. Arash et al. developed CNF/ chitosan composite as a drug carrier for preparing a $\mathrm{pH}$ responsive drug delivery system for treating trichomoniasis. The chitosan nanocapsules were prepared by embedding chitosan polymer on magnetic nanoparticles as the template. The nanocapsules were doped with CNF by tannic acid as nanochips for the delivery of drug to the target sites. The developed $\mathrm{CNF} /$ chitosan system was biocompatible and demonstrated $\mathrm{pH}$-response drug release (Yunessnia lehi et al., 2019). Table 4 summarizes the development of different nanocellulose-based scaffolds with a variety of materials for drug delivery applications. 


\section{Synthetic Organs \\ Bone and Cartilage}

Bone is a hard, dynamic, and complex tissue. Although it has the ability to regenerate in case of small damage or crack; however, a major injury may lead to severe bone damage that requires the introduction of a graft. The non-toxicity and good biocompatibility of certain minerals such as hydroxyapatite (Hap), silica, calcium carbonate and chloride, and nanoclay have led to their use in biomedical applications. In addition, nanoclays are known as good mechanical reinforcement agents. Hap, which is a phosphate mineral comprising calcium phosphate and is otherwise known as bone mineral, has been used in bone grafting (Ullah et al., 2020) and for bone drug delivery (Ullah I. et al., 2019).

A number of reports have shown impregnation of the cellulose matrix with Hap for bone regeneration applications (Wang et al., 2011; Luo et al., 2014; Ramani and Sastry, 2014). For instance, Fang et al. utilized phosphorylated BNC to induce the formation of calcium phosphate in the BNC matrix; the average pore diameter of the BNC-Hap composites was approximately $1 \mu \mathrm{m}$ while that of the control BNC was around $100 \mathrm{~nm}$. Moreover, the BNC-Hap composites showed better osteoblast proliferation and mesenchymal stem cell differentiation, although no external differentiation markers were supplied (Fang et al., 2009). The synthesis of BC composites with calcium-deficient hydroxyapatite (BNC-CdHap) has also been reported for bone regeneration applications. The authors reported enhanced osteoprogenitor cell adhesion on the BNC-CdHap surface, indicating that these composite scaffolds are suitable for bone regeneration applications and suggested further investigation (Zimmermann et al., 2011). Grande et al. developed BNC-Hap nanocomposites through an in-situ impregnation method (Grande et al., 2009). The nanocomposites were found suitable for biomedical applications. Wan et al. phosphorylated BNC to enhance its ability to induce Hap production, for which it was better than pristine BNC (Wan et al., 2007). Hutchens et al. fabricated BNC-Hap nanocomposites mimicking the biomineralization of natural bone (Hutchens et al., 2006). Silica, the major constituent of sand, is obtained through quartz purification and sand mining. Yano et al. synthesized BC-silica composites through both in-situ and ex-situ impregnation methods (Yano et al., 2008). Maeda et al. fabricated BC-silica composites via an ex-situ method followed by hot pressing; the composites showed high tensile strength (185 MPa) and Young's modulus (17 GPa) (Maeda et al., 2006). BC-silica composites have also been proposed as aerogels (Cai et al., 2012), light-emitting materials (Barud et al., 2008; Cai et al., 2012), and adsorbents for water purification (Sai et al., 2013). Mineralized tissues also contain calcium carbonate $\left(\mathrm{CaCO}_{3}\right)$ (Stoica-Guzun et al., 2012), and $\mathrm{BNC}-\mathrm{CaCO}_{3}$ composites have been synthesized (Serafica et al., 2002; Shi et al., 2009). StoicaGuzun et al. studied the effect of $\mathrm{CaCO}_{3}$ on $\mathrm{BNC}$ pellicles using sodium carbonate $\left(\mathrm{NaCO}_{3}\right)$ and calcium chloride $\left(\mathrm{CaCl}_{2}\right)$ as reactants; bigger crystals of $\mathrm{BNC}-\mathrm{CaCO}_{3}$ composites with different shapes were obtained in ultrasound-irradiated samples compared to non-irradiated samples (Stoica-Guzun et al., 2012). They also studied the effect of microwave irradiation using the same reactants and found diverse polymorphism and substantial morphological differences for irradiated $\mathrm{BNC}-\mathrm{CaCO}_{3}$ crystals were found suitable for medical and industrial applications (Stoica-Guzun et al., 2013). The surface chemistry and physical features have been further improved by developing BNC composites with calcium phosphates (de Olyveira et al., 2017). Saska et al. impregnated BC with calcium chloride $\left(\mathrm{CaCl}_{2}\right)$ and sodium hydrogen phosphate $\left(\mathrm{Na}_{2} \mathrm{HPO}_{4}\right)$; the obtained composites were effective for defect regeneration in rat tibial bones with complete bone regeneration within 4 weeks of implantation without any inflammation (Saska et al., 2011). Researchers have shown that polymer nanoclay composites show good thermal and mechanical stability, biodegradability, and barrier properties (Algar et al., 2016). Perotti et al. fabricated BNC-laponite clay nanocomposites with different $\mathrm{BNC}$ to clay ratios through ex-situ penetration from a water suspension of the clay. The obtained nanocomposites were uniform and stable with good tensile strength and Young's modulus (Perotti et al., 2011). Ul-Islam et al. synthesized BNC-montmorillonite (MMT) composites with different MMT concentrations. When testing their antimicrobial property against Staphylococcus aureus and Escherichia coli, they found better antibacterial properties with higher MMT concentrations (Ul-Islam, Khan, et al., 2013).

In addition to BNC, Kapender et al. prepared an injectable biological hydrogel comprised of nanocellulose and PVA. Herein, the nanocellulose reduced the surface features of PVA hydrogel and improved the internal structural stability of the composite hydrogel. The developed composite hydrogel demonstrated enhanced physiological properties and remained stable at ambient temperature. Importantly, the increasing concentration up to a certain limit enhanced the injectability of the hydrogel. The nanocellulose/PVA scaffold supported the growth of osteoblasts in vitro and regenerated the damaged bone tissues in vivo. Most importantly, the scaffold showed in vivo degradation at a slow rate, thus prevents the second surgery for removal of scaffolds and enhanced the bone recovery rate (Phogat et al., 2020). The outcomes of the study show that nanocellulosebased scaffolds could be a suitable candidate for developing tissue engineering scaffolds. In another study, Huang et al. developed a porous and lightweight scaffold for bone tissue engineering application by in-situ coating the CNCs matrix with Hap. The mechanical strength and water stability of the scaffold were improved by cross-linking with polymethyl vinyl ether malonic acid (PMVEMA) and polyethylene glycol. Furthermore, the scaffold demonstrated high in vitro biocompatibility and stabilized the bovine serum albumin, thus demonstrated their potential for bone tissue engineering applications (Huang et al., 2018).

\section{Neural Tissues}

Neurons represent the longest cells in the body that perform important functions in the body, such as receiving sensory signals from the external environment and sending commands to muscles. These have limited regeneration ability; nevertheless, the neuronal stem cells can self-renew and differentiate into neurons under appropriate growth conditions when cultured 
on a scaffold. An earlier study reported the differentiation of neural stem cells on the surface of a stiff surface of a biological scaffold (Leipzig and Shoichet, 2009).

The damage to neural tissues can be restored by developing neural implants, which are synthetic devices capable of stimulating parts and structure of the nervous system through electrical circuitry or electrical activity of the neurons. The conductive composite materials, such as those containing polymers and nanoparticles, could be used in the development of neural implants due to their conductive nature and biocompatibility. In another study, nanocarbon/cellulose hybrid hydrogel was prepared through in-situ modification of BNC by using the amphiphilic comb-like polymer (APCLP) as a stabilizer. The developed hydrogel demonstrated enhanced neuronal bilayer formation (Kim et al., 2017). In another study, Kuzmenko et al. formulated an ink comprised of CNF and carbon nanotubes that was printed into $3 \mathrm{D}$ scaffolds. The printed scaffolds supported the adhesion, growth, proliferation, infiltration, and differentiation of neurons (Kuzmenko et al., 2018). Compared to the conventionally prepared nanocellulose-based scaffold, the $3 \mathrm{D}$ scaffolds could be a better choice for treating various neural damages.

\section{Cardiovascular Tissues}

The cardiovascular system, also known as the blood circulatory system, is a complex system comprised of heart, heart valves, and blood vessels (arteries, capillaries, and veins). Any damage or irregularity to these organs leads to the development of different cardiovascular diseases. Some of these diseases could be treated by implanting synthetic drafts. The materials used in the development of synthetic drafts or implants must demonstrate certain features such as oxygen uptake, nitric oxide production, response to shear stress, anticoagulation, and biocompatibility (Wang D. et al., 2020). Due to the biocompatible and immunocompatible nature of nanocellulose, it can be used in the development of different cardiovascular devices such as artificial blood vessels, heart valves, aorta, prostheses, and others. In an earlier study, Millon and Wan developed CNF/ PVA nanocomposite that demonstrated high mechanical strength comparable to the heart valve and aorta (Millon and Wan, 2006). In another study, a BNC-based tubular structure was developed that supported the adhesion and proliferation of human umbilical vein endothelial cells (HUVECs), smooth muscle cells (SMCs), and fibroblasts, thus could be ideal for developing artificial blood vessels (Zang et al., 2015). To date, several nanocellulose-based products such as BASYC ${ }^{\circledR}$, Securian ${ }^{\circledR}$, and SyntheCel ${ }^{\circledast}$ have been commercialized for their use as cardiovascular implants (Ludwicka et al., 2016).

\section{Cornea}

The eye is a complex organ in the body. In the eye, the eyelids, conjunctiva, and tear glands protect the cornea from injury and maintain its transparency. Any damage to the cornea can be treated by using implants, which should possess high mechanical strength, optical transparency, biocompatibility, permeability to oxygen, and support the epithelization (Wang J. et al., 2010). In an earlier study, a nanocellulose-based scaffold supported the adhesion and proliferation of corneal stromal cells (Jia et al., 2009). In another study, Tummala et al. developed composite hydrogel based on PVA and CNCs. The developed composite demonstrated macroporous $3 \mathrm{D}$ network structure and high optical transparency. Furthermore, the scaffold supported the in vitro growth of human corneal epithelial cells (HCE-2 cells) and showed a high affinity for protein. The findings of this study demonstrate the potential of CNC/PVA scaffold for their use in the development of ophthalmic applications (Tummala et al., 2019); however, it warrants further investigation regarding the in vivo toxicity and stability analyses prior to clinical and commercial use.

\section{Dental Implants}

Dental implants are the mechanical anchors placed in the mandible which allow the adhesion and growth of cells and tissues around the grooves. These further allow the remodeling of bone around the implant. The materials used in the development of dental implants must demonstrate certain features such as high mechanical strength, porosity, biocompatibility, and non-toxicity. The success of implanting material depends on its overloading, surface features and microgap, abutment connection, material type, bone quality, and implant position and geometry (Nimbalkar et al., 2020). Different types of nanocellulose have shown promising results for their use in the development of dental implants. An earlier study developed a BNC-based composite with sodium alginate as a dressing material for surgical wounds in the oral mucosa (Chiaoprakobkij et al., 2011). Similarly, the cellulose whiskers with commercial mineral trioxide aggregate as a reinforcement material showed accelerated hardening (Jinga et al., 2014). The outcomes of these studies demonstrate the potential of nanocellulose in the development of dental implants.

Table 5 summarizes the development of different nanocellulose-based scaffolds with a variety of materials for the development of different synthetic organs.

\section{D Bioprinting}

Currently, researchers are paying great attention to tissue engineering using advanced technologies such as $3 \mathrm{D}$ bioprinting (Aljohani et al., 2018; McCarthy et al., 2019b, 2019a). The successful proliferation of animal cells on biopolymers has led to the development of three-dimensional (3D) scaffolds for in vivo tissue engineering and regenerative medicine applications. An ideal 3D scaffold must be biocompatible and nontoxic and must possess appropriate surface chemistry to support the adhesion, proliferation, and differentiation of cells, as well as resemble the micro-scale morphology of ECM (Kim and Kim, 2015). Moreover, the 3D scaffold needs to have uniform and interconnected pores to facilitate the cell infiltration, vascularization, and nutrients and waste exchange, besides possessing suitable mechanical strength to assist the tissue formation without breakage (Banerjee and Park, 2015; Wu et al., 2015). To date, cellulose has been little evaluated for its ability to form bioink for 3D printing due to its high rheology and stable structure that makes it hard to dissolve in common solvents. However, the potential advantages of using 
TABLE 5 | The improved properties and development of synthetic organs prepared from nanocellulose-based composites.

\begin{tabular}{|c|c|c|c|c|}
\hline $\begin{array}{l}\text { Cellulose type and } \\
\text { reinforcement material }\end{array}$ & Synthetic strategy & Improved/added properties & Applications & References \\
\hline $\begin{array}{l}\text { Gelatin, hydroxyapatite, and } \\
\text { procyanidins }\end{array}$ & Ex-situ & Porosity, mechanical strength, cell viability, in vivo bone formation & $\begin{array}{l}\text { Bone tissue } \\
\text { engineering }\end{array}$ & Huang et al. (2017) \\
\hline Hydroxyapatite, CNC & - & Improved thermal properties, biocompatible & $\begin{array}{l}\text { Bone tissue } \\
\text { engineering }\end{array}$ & $\begin{array}{l}\text { Niamsap et al. } \\
(2019)\end{array}$ \\
\hline $\begin{array}{l}\text { Hydroxyapatite and graphene } \\
\text { oxide }\end{array}$ & Ex-situ & $\begin{array}{l}\text { Water uptake, in vitro degradation, cell adhesion and growth, and } \\
\text { ALP activity }\end{array}$ & $\begin{array}{l}\text { Bone tissue } \\
\text { engineering }\end{array}$ & $\begin{array}{l}\text { Ramani and Sastry, } \\
\text { (2014) }\end{array}$ \\
\hline HAp & $\begin{array}{l}\text { Post-synthesis } \\
\text { loading }\end{array}$ & $\begin{array}{l}\mathrm{Ca}^{2+} \text { and } \mathrm{PO}_{4}{ }^{2-} \text { present, significant improvement of osteoblast } \\
\text { growth, adhesion, and osteoconductivity on BC-HAp membranes }\end{array}$ & & Tazi et al. (2012) \\
\hline $\mathrm{BNC}$ & 3D printing & Biocompatible and suitable mechanical properties & $\begin{array}{l}\text { Artificial kidney and } \\
\text { liver }\end{array}$ & $\begin{array}{l}\text { Recouvreux et al. } \\
\text { (2011) }\end{array}$ \\
\hline $\mathrm{BNC}$ & In-situ & Bilayer, mechanical stability, porous & $\begin{array}{l}\text { Neo cartilage } \\
\text { formation }\end{array}$ & $\begin{array}{l}\text { Martínez Ávila et al. } \\
\text { (2015) }\end{array}$ \\
\hline BNC and agarose & Molding & Aligned fiber & $\begin{array}{l}\text { Neural cell } \\
\text { proliferation }\end{array}$ & Zang et al. (2014) \\
\hline BNC & In-situ & Tubular structure, biocompatible & Blood vessels & Lin et al. (2013) \\
\hline BNC and polydimethylsiloxane & Molding & Tubular and biocompatible & $\begin{array}{l}\text { Artificial blood } \\
\text { vessels }\end{array}$ & Zang et al. (2015) \\
\hline BNC & Freeze-drying & Biocompatible, transparent, and suitable mechanical properties & Artificial cornea & Jia et al. (2009) \\
\hline GO & Ex-situ & Less crystalline & $\begin{array}{l}\text { Neural cell } \\
\text { proliferation }\end{array}$ & Kim et al. (2017) \\
\hline Fibrin & Ex-situ & Biocompatible & Vascular graft & $\begin{array}{l}\text { Karimian et al. } \\
\text { (2019) }\end{array}$ \\
\hline Peptide & Crosslinking & Biocompatible & Blood vessels & Lin et al. (2013) \\
\hline BNC and PVA & Ex-situ & Suitable mechanical properties and anisotropic behavior & Heart valve & Mohammadi, (2011) \\
\hline BNC and PVA & Ex-situ & $\begin{array}{l}\text { Transparent, UV absorbent, high mechanical strength, and thermal } \\
\text { stability }\end{array}$ & Artificial cornea & Wang et al. (2010a) \\
\hline CNC and ionic liquids & Regeneration & Transparent, high WHC & Ocular bandage & Patchan et al. (2013) \\
\hline BNC, otoliths, and collagen & $\begin{array}{l}\text { Post-synthesis } \\
\text { loading }\end{array}$ & $\begin{array}{l}\text { Formation of bone tissue with higher osteoblast activity, high degree } \\
\text { of regularity, and osteo-reabsorption activities }\end{array}$ & $\begin{array}{l}\text { Bone tissue } \\
\text { engineering }\end{array}$ & Olyveira et al. (2011) \\
\hline $\mathrm{BNC}$ and $\mathrm{Col}_{1}$ & $\begin{array}{l}\text { Post-synthesis } \\
\text { cross-linking }\end{array}$ & $\begin{array}{l}\text { Tensile strength and elastic modulus for } \mathrm{BC}-\mathrm{Col}_{1} \text { decreased, a slight } \\
\text { increase in strain at break, similar cell morphology, and cell } \\
\text { proliferation/viability }\end{array}$ & $\begin{array}{l}\text { Bone tissue } \\
\text { engineering }\end{array}$ & Saska et al. (2012) \\
\hline
\end{tabular}

TABLE 6 | The improved properties, 3D printing, and biomedical applications of different nanocellulose-based composites.

\begin{tabular}{|c|c|c|c|c|c|}
\hline $\begin{array}{l}\text { Cellulose } \\
\text { type }\end{array}$ & $\begin{array}{l}\text { Reinforcement } \\
\text { material }\end{array}$ & Synthetic strategy & $\begin{array}{l}\text { Improved/added } \\
\text { properties }\end{array}$ & Applications & References \\
\hline CNF & Alginate & $\begin{array}{l}\text { 3D extrusion } \\
\text { printing }\end{array}$ & 3D structure, biocompatible & Cartilage regeneration & Markstedt et al. (2015) \\
\hline CNCs & PEGDA & 3D printing & Mechanical, thermal, and biological properties & Tissue scaffold & NB et al. (2017) \\
\hline BNC & - & 3D printing & Biocompatible and suitable mechanical properties & Artificial kidney and liver & $\begin{array}{l}\text { Recouvreux et al. } \\
\text { (2011) }\end{array}$ \\
\hline CNFs & Alginate & 3D printing & $\begin{array}{l}\text { Porosity, mechanical strength, crosslinking, } \\
\text { biocompatibility }\end{array}$ & Tissue scaffold & Abouzeid et al. (2018) \\
\hline
\end{tabular}

nanocellulose in the development of 3D printed scaffolds are quite clear, and some earlier success reports are available. For example, Recouvreux et al. synthesized an organ-like 3D hydrogel of $\mathrm{BC}$ and characterized its structural features, mechanical strength, and biocompatibility; they believe it has potential as an implantable tissue and organ scaffold for organs such as the kidney or liver (Recouvreux et al., 2011). In another study, de Souza, Olival-Costa et al. implanted a BC membrane in rabbits and investigated its response in terms of medialization, inflammation, and healing of the vocal folds; the $\mathrm{BC}$ membrane remained stable for 120 days and did not demonstrate any major drawbacks, indicating its suitability for the medial displacement of the vocal folds (De Souza et al., 2011). In another study, a BNC-based ear-shaped model was created from the reconstruction of gradient-echo magnetic resonance imaging. For this purpose, Nimeskern et al. bioprinted BNC using a negative silicone mold by manipulating the bacterial activity to reproduce the large-scale features of the outer ear to generate patient-specific ear shapes (Nimeskern et al., 2013). In another study, a conductive ink comprised of CNF and CNTs was formulated and printed under optimized conditions of $\mathrm{pH}$ dependent surface charges. The 3D printed scaffold supported 
TABLE 7 | The improved properties and biosensing applications of different nanocellulose-based composites.

\begin{tabular}{|c|c|c|c|c|}
\hline Reinforcement material & $\begin{array}{l}\text { Synthetic } \\
\text { strategy }\end{array}$ & Improved/added properties & Applications & References \\
\hline $\begin{array}{l}\text { Poly aniline and carbon } \\
\text { nanotubes }\end{array}$ & Ex-situ & Thermal stability, electrical conductivity & $\begin{array}{l}\text { Biosensors, solar cells, bio- } \\
\text { electronic devices }\end{array}$ & Jasim et al. (2017) \\
\hline $\begin{array}{l}\text { Carbon nanotubes and poly } \\
\text { (ethylene imine) }\end{array}$ & Ex-situ & $\begin{array}{l}\text { Sites for phage immobilization, Mechanical strength, } \\
\text { conductivity, antibacterial activity, stability of the sensor }\end{array}$ & Biosensing & $\begin{array}{l}\text { Farooq et al. } \\
(2020)\end{array}$ \\
\hline $\mathrm{CNC}$ and $\mathrm{GO}$ & Ex-situ & Proximity sensing ability & $\begin{array}{l}\text { Optoelectronic sensing } \\
\text { devices }\end{array}$ & $\begin{array}{l}\text { Sadasivuni et al. } \\
\text { (2015) }\end{array}$ \\
\hline CNC and GO & Ex-situ & Flexible, transparent, conductive & Biofluid separation & Xiong et al. (2016) \\
\hline
\end{tabular}

the adhesion, proliferation, and differentiation of neuronal cells (Kuzmenko et al., 2018). These advancements demonstrate the potential of nanocellulose as a promising material in tissue engineering for the development of a wide range of materials, such as for treating spinal cord injury (Bedir et al., 2020).

Table 6 summarizes the development of different 3D printed nanocellulose-based scaffolds for biomedical applications.

\section{Biosensing}

Biosensing is a mechanism of detecting a biomolecule, a biological structure, or a microorganism by using a biosensor. A biosensor is an analytical device that transforms the biological response into an output signal by using the biorecognition elements such as enzymes, antibodies, nucleic acids, and bacteriophages (Farooq et al., 2018). Nanocellulose, owing to its unique surface chemistry, high surface area, high aspect ratio, flexibility, mechanical strength, and biocompatibility, could be an ideal material for the development of biosensors. Although nanocellulose is nonconductive, its composites with conductive polymers and nanoparticles demonstrate electrical conductivity and thus could be used in the development of biosensors. In a study, Jasim et al. modified the fibers in BNC with polyaniline through oxidative polymerization and further impregnated the modified fibers with single-walled carbon nanotubes. The developed composite showed high electrical conductivity and thus could be used in the development of a biosensor. Abdi et al. developed an electrochemical biosensor by combining CNC, polyaniline, and ionic liquid on a modified screen-printed electrode. Herein, cholesterol oxidase was used as the biorecognition element for the detection of cholesterol level. The developed biosensor showed operational repeatability, low limit of detection, and high sensitivity (Abdi et al., 2019). In another study, Farooq et al. developed an electrochemical biosensor based on BNC by using a phage as the biorecognition element. They first carboxylated the BNC and then modified it with polyethyleneimine (PEI) to allow an electrostatic interaction between the negatively charged phages and positively charged BNC/PEI matrix. The modified BNC/PEI matrix was impregnated with carbon nanotubes. The modified matrix allowed the immobilization of phages. The developed sensor effectively detected $S$. aureus and differentiated the live and dead cells (Farooq et al., 2020). Nanocellulose-based sensors have also been developed for the detection of glucose level in the blood (Wang W. et al., 2010). These nanocellulose-based sensors offer several advantages like low cost, reproducibility, stability, and biocompatibility. Table 7 summarizes the development of different nanocellulose-based scaffolds with a variety of materials for biosensing applications.

\section{CONCLUSION AND FUTURE PERSPECTIVE}

As a biodegradable, non-toxic, and renewable material with appropriate mechanical strength, nanocellulose-based hydrogels have been proved to be a promising material for tissue engineering and regenerative medicine applications. In this review, the preparation methods of nanocellulose-based hydrogels are introduced, and their applications in biomedicine and tissue engineering are summarized, especially in developing tissue engineering scaffolds, wound dressings, drug carriers, synthetic organs, biosensing materials, and 3D printed scaffolds. However, there are several problems in the application of nanocellulosebased hydrogels in bioengineering in the research process.

First, the long-term biosafety of hydrogels made by CNCs and CNFs in biomedicine has not been evaluated systematically. Although natural cellulose such as BNC is biocompatible and non-toxic, most of these studies are based on cell or histopathological experiments or short-term examinations. For example, when the nanocellulose-based hydrogel is applied to drug delivery systems, the long-term effects of these drug carriers, including the long-term toxicity, biocompatibility, immunogenicity, pharmacokinetics, and pharmacodynamics, should be verified in animal models before the clinical transformation. Secondly, the nanocellulose-based hydrogels are reported to be a highquality tissue engineering scaffold for direct application in humans; however, these lack innate antibacterial, antioxidant, and regenerative activity, thus the nanocellulose-based biomaterials need the impregnation or doping of antibiotics or additives to enhance their biological activity such as for tissue regeneration and preventing the infection properly. Third, it is often difficult to load drugs or cells into the hydrogels for controlled drug delivery, which requires further design of hydrogels. To ensure the biological safety of hydrogel during drug delivery, attention should be paid to its preparation, such 
as by developing innoxious solvent, green synthesis method, and the non-toxic crosslinking agent.

The optimization of the synthesis process, post-synthesis processing, and improving the physical and chemical modification methods of nanocellulose-based hydrogels can expand their applications to new areas and reach the stage of commercialization. For instance, the development of effective wound dressings, controlled and sustained-release drug delivery systems, and developing stimulus-response types sensitive to $\mathrm{pH}$, temperature, humidity, infection, etc., can have potential clinical applications.

\section{DATA AVAILABILITY STATEMENT}

The original contributions presented in the study are included in the article/Supplementary Material, further inquiries can be directed to the corresponding authors.

\section{AUTHOR CONTRIBUTIONS}

CW: collate the literature responsible for introducing nanocellulose and hydrogel preparation materials and methods

\section{REFERENCES}

Abdi, M. M., Razalli, R. L., Tahir, P. M., Chaibakhsh, N., Hassani, M., and Mir, M. (2019). Optimized Fabrication of Newly Cholesterol Biosensor Based on Nanocellulose. Int. J. Biol. Macromolecules 126, 1213-1222. doi:10.1016/ j.ijbiomac.2019.01.001

Abe, K., and Yano, H. (2012). Cellulose Nanofiber-Based Hydrogels with High Mechanical Strength. Cellulose 19, 1907-1912. doi:10.1007/s10570-0129784-3

Abe, K., and Yano, H. (2011). Formation of Hydrogels from Cellulose Nanofibers. Carbohydr. Polym. 85, 733-737. doi:10.1016/j.carbpol.2011.03.028

Abouzeid, R. E., Khiari, R., Beneventi, D., and Dufresne, A. (2018). Biomimetic Mineralization of Three-Dimensional Printed Alginate/TEMPO-Oxidized Cellulose Nanofibril Scaffolds for Bone Tissue Engineering. Biomacromolecules 19, 4442-4452. doi:10.1021/ACS.BIOMAC.8B01325

Al-Sabah, A., Burnell, S. E. A., Simoes, I. N., Jessop, Z., Badiei, N., Blain, E., et al. (2019). Structural and Mechanical Characterization of Crosslinked and Sterilised Nanocellulose-Based Hydrogels for Cartilage Tissue Engineering. Carbohydr. Polym. 212, 242-251. doi:10.1016/j.carbpol.2019.02.057

Algar, I., Garcia-Astrain, C., Gonzalez, A., Martin, L., Gabilondo, N., Retegi, A., et al. (2016). Improved Permeability Properties for Bacterial Cellulose/ Montmorillonite Hybrid Bionanocomposite Membranes by In-Situ Assembling. J. Renew. Mater. 4, 57-65. doi:10.7569/JRM.2015.634124

Aljohani, W., Ullah, M. W., Zhang, X., and Yang, G. (2018). Bioprinting and its Applications in Tissue Engineering and Regenerative Medicine. Int. J. Biol. Macromolecules 107, 261-275. doi:10.1016/j.ijbiomac.2017.08.171

Ao, C., Niu, Y., Zhang, X., He, X., Zhang, W., and Lu, C. (2017). Fabrication and Characterization of Electrospun Cellulose/nano-Hydroxyapatite Nanofibers for Bone Tissue Engineering. Int. J. Biol. Macromolecules 97, 568-573. doi:10.1016/ j.ijbiomac.2016.12.091

Ao, H., Jiang, W., Nie, Y., Zhou, C., Zong, J., Liu, M., et al. (2020). Engineering Quaternized Chitosan in the 3D Bacterial Cellulose Structure for Antibacterial Wound Dressings. Polym. Test. 86, 106490. doi:10.1016/ j.polymertesting.2020.106490

Arafiles, J. V. V., and Futaki, S. (2021). Chemical Passports to Cross Biological Borders. Nat. Chem. 13 (13), 517-519. doi:10.1038/s41557-021-00694-2 and writing the corresponding parts of the article. JB: is responsible for summarizing the related applications of nanocellulose hydrogel in biomedicine and summarizing the overall contents of the article. PT: responsible for searching relevant literature, sorting out references, and writing articles. QL: responsible for the translation and polishing of articles.

\section{FUNDING}

This work was financially supported by the Innovation training program of Hunan Province, Project number: S202110555137. The National Natural Science Foundation of China (grant number 51802147), The Natural Science Foundation of Hunan Province, China (grant number 2016JJ3105).

\section{ACKNOWLEDGMENTS}

Authors are thankful to the school of chemistry and chemical engineering, University of South China, China for the quality education and moral support. They would also like to acknowledge the financial support of the innovation training program of Hunan Province, China.

Arfin, T. (2020). Cellulose and Hydrogel Matrices for Environmental Applications. Sustain. Nanocellulose Nanohydrogels Nat. Sourc., 255-274. doi:10.1016/B9780-12-816789-2.00012-2

Atta, O. M., Manan, S., Ahmed, A. A. Q., Awad, M. F., Ul-Islam, M., Subhan, F., et al. (2021). Development and Characterization of Yeast-Incorporated Antimicrobial Cellulose Biofilms for Edible Food Packaging Application. Polymers 13, 2310. doi:10.3390/polym 13142310

Banerjee, N., and Park, J. (2015). Modeling and Simulation of Biopolymer Networks: Classification of the Cytoskeleton Models According to Multiple Scales. Korean J. Chem. Eng. 32, 1207-1217. doi:10.1007/s11814-015-0071-5

Barud, H. S., Assunção, R. M. N., Martines, M. A. U., Dexpert-Ghys, J., Marques, R. F. C., Messaddeq, Y., et al. (2008). Bacterial Cellulose-Silica Organic-Inorganic Hybrids. J. Sol-gel Sci. Technol. 46, 363-367. doi:10.1007/s10971-007-1669-9

Bedir, T., Ulag, S., Ustundag, C. B., and Gunduz, O. (2020). 3D Bioprinting Applications in Neural Tissue Engineering for Spinal Cord Injury Repair. Mater. Sci. Eng. C 110, 110741. doi:10.1016/j.msec.2020.110741

Boateng, J. S., Matthews, K. H., Stevens, H. N. E., and Eccleston, G. M. (2008). Wound Healing Dressings and Drug Delivery Systems: A Review. J. Pharm. Sci. 97, 2892-2923. doi:10.1002/JPS.21210

Bonilla, M. R., Lopez-Sanchez, P., Gidley, M. J., and Stokes, J. R. (2016). Micromechanical Model of Biphasic Biomaterials with Internal Adhesion: Application to Nanocellulose Hydrogel Composites. Acta Biomater. 29, 149-160. doi:10.1016/j.actbio.2015.10.032

Boyer, C., Figueiredo, L., Pace, R., Lesoeur, J., Rouillon, T., Visage, C. L., et al. (2018). Laponite Nanoparticle-Associated Silated Hydroxypropylmethyl Cellulose as an Injectable Reinforced Interpenetrating Network Hydrogel for Cartilage Tissue Engineering. Acta Biomater. 65, 112-122. doi:10.1016/J.ACTBIO.2017.11.027

Cai, J., Liu, S., Feng, J., Kimura, S., Wada, M., Kuga, S., et al. (2012). Cellulose-Silica Nanocomposite Aerogels by In Situ Formation of Silica in Cellulose Gel. Angew. Chem. Int. Ed. 51, 2076-2079. doi:10.1002/anie.201105730

Chen, W., Yu, H., Lee, S.-Y., Wei, T., Li, J., and Fan, Z. (2018a). Nanocellulose: A Promising Nanomaterial for Advanced Electrochemical Energy Storage. Chem. Soc. Rev. 47, 2837-2872. doi:10.1039/c7cs00790f

Chen, X., Xu, X., Li, W., Sun, B., Yan, J., Chen, C., et al. (2018b). Effective Drug Carrier Based on Polyethylenimine-Functionalized Bacterial Cellulose with Controllable Release Properties. ACS Appl. Bio Mater. 1, 42-50. doi:10.1021/ acsabm.8b00004 
Chen, Y., Liu, C., Chang, P. R., Cao, X., and Anderson, D. P. (2009). Bionanocomposites Based on Pea Starch and Cellulose Nanowhiskers Hydrolyzed from Pea hull Fibre: Effect of Hydrolysis Time. Carbohydr. Polym. 76, 607-615. doi:10.1016/j.carbpol.2008.11.030

Chiaoprakobkij, N., Sanchavanakit, N., Subbalekha, K., Pavasant, P., and Phisalaphong, M. (2011). Characterization and Biocompatibility of Bacterial Cellulose/alginate Composite Sponges with Human Keratinocytes and Gingival Fibroblasts. Carbohydr. Polym. 85, 548-553. doi:10.1016/j.carbpol.2011.03.011

Cielecka, I., Szustak, M., Gendaszewska-Darmach, E., Kalinowska, H., Ryngajłło, M., Maniukiewicz, W., et al. (2018). Novel Bionanocellulose/א-Carrageenan Composites for Tissue Engineering. Appl. Sci. 8, 1352. doi:10.3390/app8081352

Curvello, R., Raghuwanshi, V. S., and Garnier, G. (2019). Engineering Nanocellulose Hydrogels for Biomedical Applications. Adv. Colloid Interf. Sci. 267, 47-61. doi:10.1016/j.cis.2019.03.002

De France, K. J., Hoare, T., and Cranston, E. D. (2017). Review of Hydrogels and Aerogels Containing Nanocellulose. Chem. Mater. 29, 4609-4631. doi:10.1021/ ACS.CHEMMATER.7B00531

de Olyveira, G. M., Basmaji, P., Costa, L. M. M., dos Santos, M. L., dos Santos Riccardi, C., Guastaldi, F. P. S., et al. (2017). Surface Physical Chemistry Properties in Coated Bacterial Cellulose Membranes with Calcium Phosphate. Mater. Sci. Eng. C 75, 1359-1365. doi:10.1016/j.msec.2017.03.025

De Souza, F. C., Olival-Costa, H., Da Silva, L., Pontes, P. A., and Lancellotti, C. L. P. (2011). Bacterial Cellulose as Laryngeal Medialization Material: An Experimental Study. J. Voice 25, 765-769. doi:10.1016/j.jvoice.2010.07.005

Di, Z., Shi, Z., Ullah, M. W., Li, S., and Yang, G. (2017). A Transparent Wound Dressing Based on Bacterial Cellulose Whisker and Poly(2-Hydroxyethyl Methacrylate). Int. J. Biol. Macromolecules 105, 638-644. doi:10.1016/j.ijbiomac.2017.07.075

Dutta, S. D., Patel, D. K., and Lim, K.-T. (2019). Functional Cellulose-Based Hydrogels as Extracellular Matrices for Tissue Engineering. J. Biol. Eng. 13. doi:10.1186/S13036-019-0177-0

Fang, B., Wan, Y.-Z., Tang, T.-T., Gao, C., and Dai, K.-R. (2009). Proliferation and Osteoblastic Differentiation of Human Bone Marrow Stromal Cells on Hydroxyapatite/Bacterial Cellulose Nanocomposite Scaffolds. Tissue Eng. A 15, 1091-1098. doi:10.1089/ten.tea.2008.0110

Farooq, U., Ullah, M. W., Yang, Q., Aziz, A., Xu, J., Zhou, L., et al. (2020). Highdensity Phage Particles Immobilization in Surface-Modified Bacterial Cellulose for Ultra-sensitive and Selective Electrochemical Detection of Staphylococcus aureus. Biosens. Bioelectron. 157, 112163. doi:10.1016/j.bios.2020.112163

Farooq, U., Yang, Q., Ullah, M. W., and Wang, S. (2018). Bacterial Biosensing: Recent Advances in Phage-Based Bioassays and Biosensors. Biosens. Bioelectron. 118, 204-216. doi:10.1016/j.bios.2018.07.058

Fatima, A., Yasir, S., Khan, M. S., Manan, S., Ullah, M. W., and Ul-Islam, M. (2021). Plant Extract-Loaded Bacterial Cellulose Composite Membrane for Potential Biomedical Applications. J. Bioresources Bioproducts 6, 26-32. doi:10.1016/ j.jobab.2020.11.002

Grande, C. J., Torres, F. G., Gomez, C. M., and Carmen Bañó, M. (2009). Nanocomposites of Bacterial Cellulose/hydroxyapatite for Biomedical Applications. Acta Biomater. 5, 1605-1615. doi:10.1016/j.actbio.2009.01.022

Grishkewich, N., Mohammed, N., Tang, J., and Tam, K. C. (2017). Recent Advances in the Application of Cellulose Nanocrystals. Curr. Opin. Colloid Interf. Sci. 29, 32-45. doi:10.1016/j.cocis.2017.01.005

G., S., R., M., and H., B. (2002). Inclusion of Solid Particles in Bacterial Cellulose. Appl. Microbiol. Biotechnol. 58, 756-760. doi:10.1007/s00253-002-0978-8

Halib, N., Ahmad, I., Grassi, M., and Grassi, G. (2019). The Remarkable ThreeDimensional Network Structure of Bacterial Cellulose for Tissue Engineering Applications. Int. J. Pharmaceutics 566, 631-640. doi:10.1016/j.ijpharm.2019.06.017

Heux, L., Chauve, G., and Bonini, C. (2000). Nonflocculating and Chiral-Nematic Self-Ordering of Cellulose Microcrystals Suspensions in Nonpolar Solvents. Langmuir 16, 8210-8212. doi:10.1021/la9913957

Hong, H.-J., Kim, J., Kim, D.-Y., Kang, I., Kang, H. K., and Ryu, B. G. (2019). Synthesis of Carboxymethylated Nanocellulose Fabricated Ciprofloxacine Montmorillonite Composite for Sustained Delivery of Antibiotics. Int. J. Pharmaceutics 567, 118502. doi:10.1016/J.IJPHARM.2019.118502

Huang, L., Chen, X., Nguyen, T. X., Tang, H., Zhang, L., and Yang, G. (2013). Nano-cellulose 3D-Networks as Controlled-Release Drug Carriers. J. Mater. Chem. B 1, 2976. doi:10.1039/c3tb20149j

Huang, W., Wang, Y., Huang, Z., Wang, X., Chen, L., Zhang, Y., et al. (2018). OnDemand Dissolvable Self-Healing Hydrogel Based on Carboxymethyl Chitosan and Cellulose Nanocrystal for Deep Partial Thickness Burn Wound Healing. ACS Appl. Mater. Inter. 10, 41076-41088. doi:10.1021/acsami.8b14526

Huang, Y., Wang, J., Yang, F., Shao, Y., Zhang, X., and Dai, K. (2017). Modification and Evaluation of Micro-nano Structured Porous Bacterial Cellulose Scaffold for Bone Tissue Engineering. Mater. Sci. Eng. C 75, 1034-1041. doi:10.1016/ j.msec.2017.02.174

Hujaya, S. D., Lorite, G. S., Vainio, S. J., and Liimatainen, H. (2018). Polyion Complex Hydrogels from Chemically Modified Cellulose Nanofibrils: Structure-Function Relationship and Potential for Controlled and $\mathrm{pH}$-Responsive Release of Doxorubicin. Acta Biomater. 75, 346-357. doi:10.1016/J.ACTBIO.2018.06.013

Hutchens, S., Benson, R., Evans, B., Oneill, H., and Rawn, C. (2006). Biomimetic Synthesis of Calcium-Deficient Hydroxyapatite in a Natural Hydrogel. Biomaterials 27, 4661-4670. doi:10.1016/j.biomaterials.2006.04.032

Isogai, A., and Bergström, L. (2018). Preparation of Cellulose Nanofibers Using green and Sustainable Chemistry. Curr. Opin. Green Sustainable Chem. 12, 15-21. doi:10.1016/j.cogsc.2018.04.008

Janpetch, N., Saito, N., and Rujiravanit, R. (2016). Fabrication of Bacterial Cellulose-ZnO Composite via Solution Plasma Process for Antibacterial Applications. Carbohydr. Polym. 148, 335-344. doi:10.1016/ j.carbpol.2016.04.066

Jasim, A., Ullah, M. W., Shi, Z., Lin, X., and Yang, G. (2017). Fabrication of Bacterial Cellulose/polyaniline/single-Walled Carbon Nanotubes Membrane for Potential Application as Biosensor. Carbohydr. Polym. 163, 62-69. doi:10.1016/j.carbpol.2017.01.056

Jia, H., Jia, Y., Wang, J., Hu, Y., Zhang, Y., and Jia, S. (2009).Potentiality of Bacterial Cellulose as the Scaffold of Tissue Engineering of Cornea. Proceedings of the 2009 2nd International Conference on Biomedical Engineering and Informatics. New York, NY: BMEI. doi:10.1109/BMEI.2009.5305657

Jiji, S., Udhayakumar, S., Maharajan, K., Rose, C., Muralidharan, C., and Kadirvelu, K. (2020). Bacterial Cellulose Matrix with In Situ Impregnation of Silver Nanoparticles via Catecholic Redox Chemistry for Third Degree Burn Wound Healing. Carbohydr. Polym. 245, 116573. doi:10.1016/ J.CARBPOL.2020.116573

Jinga, S. I., Voicu, G., Stoica-Guzun, A., Stroescu, M., Grumezescu, A. M., and Bleotu, C. (2014). Biocellulose Nanowhiskers Cement Composites for Endodontic Use. Dig. J. Nanomater. Biostructures. 9, 543-550.

Kang, H.-W., Lee, S. J., Ko, I. K., Kengla, C., Yoo, J. J., and Atala, A. (2016). A 3D Bioprinting System to Produce Human-Scale Tissue Constructs with Structural Integrity. Nat. Biotechnol. 34, 312-319. doi:10.1038/nbt.3413

Karimian, A., Parsian, H., Majidinia, M., Rahimi, M., Mir, S. M., Samadi Kafil, H., et al. (2019). Nanocrystalline Cellulose: Preparation, Physicochemical Properties, and Applications in Drug Delivery Systems. Int. J. Biol. Macromolecules 133, 850-859. doi:10.1016/j.ijbiomac.2019.04.117

Khamrai, M., Banerjee, S. L., Paul, S., Ghosh, A. K., Sarkar, P., and Kundu, P. P. (2019). A Mussel Mimetic, Bioadhesive, Antimicrobial Patch Based on Dopamine-Modified Bacterial Cellulose/rGO/Ag NPs: A Green Approach toward Wound-Healing Applications. ACS Sustainable Chem. Eng. doi:10.1021/acssuschemeng.9b01163

Khan, S., Siddique, R., Huanfei, D., Shereen, M. A., Nabi, G., Bai, Q., et al. (2021). Perspective Applications and Associated Challenges of Using Nanocellulose in Treating Bone-Related Diseases. Front. Bioeng. Biotechnol. 9, 350. doi:10.3389/ fbioe.2021.616555

Khan, S., Ul-Islam, M., Khattak, W. A., Ullah, M. W., and Park, J. K. (2015a). Bacterial Cellulose-Titanium Dioxide Nanocomposites: Nanostructural Characteristics, Antibacterial Mechanism, and Biocompatibility. Cellulose 22, 565-579. doi:10.1007/s10570-014-0528-4

Khan, S., Ul-Islam, M., Ullah, M. W., Ikram, M., Subhan, F., Kim, Y., et al. (2015b). Engineered Regenerated Bacterial Cellulose Scaffolds for Application in In Vitro Tissue Regeneration. RSC Adv. 5, 84565-84573. doi:10.1039/ C5RA16985B

Khorasani, A. C., and Shojaosadati, S. A. (2017). Starch- and Carboxymethylcellulose-Coated Bacterial Nanocellulose-Pectin Bionanocomposite as Novel Protective Prebiotic Matrices. Food Hydrocolloids 63, 273-285. doi:10.1016/j.foodhyd.2016.09.002

Kim, D., Park, S., Jo, I., Kim, S.-M., Kang, D. H., Cho, S.-P., et al. (2017). Multiscale Modulation of Nanocrystalline Cellulose Hydrogel via Nanocarbon Hybridization for 3D Neuronal Bilayer Formation. Small 13, 1700331-1700410. doi:10.1002/smll.201700331 
Kim, M., and Kim, G. (2015). Physical and Biological Activities of Newly Designed, Macro-Pore-Structure-Controlled 3D Fibrous Poly( $\varepsilon$-Caprolactone)/ hydroxyapatite Composite Scaffolds. RSC Adv. 5, 26954-26964. doi:10.1039/ C5RA00915D

Kim, Y., Ullah, M. W., Ul-Islam, M., Khan, S., Jang, J. H., and Park, J. K. (2019). Self-assembly of Bio-Cellulose Nanofibrils through Intermediate Phase in a Cell-free Enzyme System. Biochem. Eng. J. 142, 135-144. doi:10.1016/ j.bej.2018.11.017

Klemm, D., Heublein, B., Fink, H.-P., and Bohn, A. (2005). Cellulose: Fascinating Biopolymer and Sustainable Raw Material. Angew. Chem. Int. Ed. 44, 3358-3393. doi:10.1002/anie.200460587

Kuzmenko, V., Karabulut, E., Pernevik, E., Enoksson, P., and Gatenholm, P. (2018). Tailor-made Conductive Inks from Cellulose Nanofibrils for 3D Printing of Neural Guidelines. Carbohydr. Polym. 189, 22-30. doi:10.1016/j.carbpol.2018.01.097

Leipzig, N. D., and Shoichet, M. S. (2009). The Effect of Substrate Stiffness on Adult Neural Stem Cell Behavior. Biomaterials 30, 6867-6878. doi:10.1016/ j.biomaterials.2009.09.002

Li, S., Jasim, A., Jasim, A., Zhao, W., Fu, L., Ullah, M. W., et al. (2018). Fabrication of $\mathrm{pH}$-Electroactive Bacterial Cellulose/Polyaniline Hydrogel for the Development of a Controlled Drug Release System. ES Mater.Manuf., 41-49. doi:10.30919/esmm5f120

Li, X., Ji, X., Chen, K., Yuan, X., Lei, Z., Ullah, M. W., et al. (2021). Preparation and Evaluation of Ion-Exchange Porous Polyvinyl Alcohol Microspheres as a Potential Drug Delivery Embolization System. Mater. Sci. Eng. C 121, 111889. doi:10.1016/j.msec.2021.111889

Lin, N., and Dufresne, A. (2014). Nanocellulose in Biomedicine: Current Status and Future prospect. Eur. Polym. J. 59, 302-325. doi:10.1016/ j.eurpolymj.2014.07.025

Lin, S.-P., Loira Calvar, I., Catchmark, J. M., Liu, J.-R., Demirci, A., and Cheng, K.C. (2013). Biosynthesis, Production and Applications of Bacterial Cellulose. Cellulose 20, 2191-2219. doi:10.1007/s10570-013-9994-3

Liu, R., Dai, L., Si, C., and Zeng, Z. (2018). Antibacterial and Hemostatic Hydrogel via Nanocomposite from Cellulose Nanofibers. Carbohydr. Polym. 195, 63-70. doi:10.1016/j.carbpol.2018.04.085

Loh, E. Y. X., Mohamad, N., Fauzi, M. B., Ng, M. H., Ng, S. F., and Mohd Amin, M. C. I. (2018). Development of a Bacterial Cellulose-Based Hydrogel Cell Carrier Containing Keratinocytes and Fibroblasts for Full-Thickness Wound Healing. Sci. Rep. 8. doi:10.1038/s41598-018-21174-7

Ludwicka, K., Jedrzejczak-Krzepkowska, M., Kubiak, K., Kolodziejczyk, M., Pankiewicz, T., and Bielecki, S. (2016). "Medical and Cosmetic Applications of Bacterial NanoCellulose," in "Chapter 9 - Medical and Cosmetic Applications of Bacterial NanoCellulose," in Bacterial Nanocellulose. Editors M. Gama, F. Dourado, and S. Bielecki (Amsterdam: Elsevier), 145-165. doi:10.1016/ B978-0-444-63458-0.00009-3

Luo, H., Ao, H., Li, G., Li, W., Xiong, G., Zhu, Y., et al. (2017). Bacterial Cellulose/ graphene Oxide Nanocomposite as a Novel Drug Delivery System. Curr. Appl. Phys. 17, 249-254. doi:10.1016/j.cap.2016.12.001

Luo, H., Zhang, J., Xiong, G., and Wan, Y. (2014). Evolution of Morphology of Bacterial Cellulose Scaffolds during Early Culture. Carbohydr. Polym. 111, 722-728. doi:10.1016/j.carbpol.2014.04.097

Luzi, F., Puglia, D., and Torre, L. (2019). "Natural Fiber Biodegradable Composites and Nanocomposites," in In Biomass, Biopolymer-Based Materials, and Bioenergy Woodhead Publishing Series in Composites Science and Engineering. Editors D. Verma, E. Fortunati, S. Jain, and X. Zhang. Cambridge, United Kingdom: Woodhead Publishing, 179-201. doi:10.1016/ B978-0-08-102426-3.00010-2

Maeda, H., Nakajima, M., Hagiwara, T., Sawaguchi, T., and Yano, S. (2006). Bacterial Cellulose/silica Hybrid Fabricated by Mimicking Biocomposites. J. Mater. Sci. 41, 5646-5656. doi:10.1007/s10853-006-0297-z

Maestri, C. A., Nakajima, M., Hagiwara, T., Sawaguchi, T., Baus, R. A., Lecca, P., et al. (2020). Composite Nanocellulose-based Hydrogels with Spatially Oriented Degradation and Retarded Release of Macromolecules. J. Biomed. Mater. Res. 108, 1509-1519. doi:10.1002/JBM.A.36922

Mao, L., Wang, L., Zhang, M., Ullah, M. W., Liu, L., Zhao, W., et al. (2021). In Situ Synthesized Selenium Nanoparticles-Decorated Bacterial Cellulose/Gelatin Hydrogel with Enhanced Antibacterial, Antioxidant, and Anti-Inflammatory Capabilities for Facilitating Skin Wound Healing. Adv. Healthc. Mater. 10, 2100402. doi:10.1002/adhm.202100402
Markstedt, K., Mantas, A., Tournier, I., Martínez Ávila, H., Hägg, D., and Gatenholm, P. (2015). 3D Bioprinting Human Chondrocytes with Nanocellulose-Alginate Bioink for Cartilage Tissue Engineering Applications. Biomacromolecules 16, 1489-1496. doi:10.1021/acs.biomac.5b00188

Martínez Ávila, H., Feldmann, E.-M., Pleumeekers, M. M., Nimeskern, L., Kuo, W., de Jong, W. C., et al. (2015). Novel Bilayer Bacterial Nanocellulose Scaffold Supports Neocartilage Formation In Vitro and In Vivo. Biomaterials 44, 122-133. doi:10.1016/j.biomaterials.2014.12.025

Masruchin, N., Park, B.-D., and Causin, V. (2017). Dual-responsive Composite Hydrogels Based on TEMPO-Oxidized Cellulose Nanofibril and poly(N-Isopropylacrylamide) for Model Drug Release. Cellulose 25, 485-502. doi:10.1007/S10570-017-1585-2

McCarthy, R. R., Ullah, M. W., Booth, P., Pei, E., and Yang, G. (2019a). The Use of Bacterial Polysaccharides in Bioprinting. Biotechnol. Adv. 37, 107448. doi:10.1016/j.biotechadv.2019.107448

McCarthy, R. R., Ullah, M. W., Pei, E., and Yang, G. (2019b). Antimicrobial Inks: The Anti-infective Applications of Bioprinted Bacterial Polysaccharides. Trends Biotechnol. 37, 1155-1159. doi:10.1016/j.tibtech.2019.05.004

Metcalfe, A. D., and Ferguson, M. W. J. (2007). Tissue Engineering of Replacement Skin: the Crossroads of Biomaterials, Wound Healing, Embryonic Development, Stem Cells and Regeneration. J. R. Soc. Interf. 4, 413-437. doi:10.1098/RSIF.2006.0179

Millon, L. E., and Wan, W. K. (2006). The Polyvinyl Alcohol-Bacterial Cellulose System as a New Nanocomposite for Biomedical Applications. J. Biomed. Mater. Res. 79B, 245-253. doi:10.1002/jbm.b.30535

Mishra, R. K., Sabu, A., and Tiwari, S. K. (2018). Materials Chemistry and the Futurist Eco-Friendly Applications of Nanocellulose: Status and prospect. J. Saudi Chem. Soc. 22, 949-978. doi:10.1016/j.jscs.2018.02.005

Mohammad, F., Bwatanglang, I. B., Al Balawi, A. N., Chavali, M., and Al-Lohedan, H. A. (2020). General Introduction on Sustainable Nanocellulose and Nanohydrogel Matrices. Sustain. Nanocellulose Nanohydrogels Nat. Sourc., 1-31. doi:10.1016/B978-0-12-816789-2.00001-8

Mohammadi, H. (2011). Nanocomposite Biomaterial Mimicking Aortic Heart Valve Leaflet Mechanical Behaviour. Proc. Inst. Mech. Eng. H 225, 718-722. doi:10.1177/0954411911399826

Moroni, L., Schrooten, J., Truckenmüller, R., Rouwkema, J., Sohier, J., and Van Blitterswijk, C. A. (2014). Tissue Engineering. Second Ed. New York, NY: Tissue Eng, 1-21. doi:10.1016/B978-0-12-420145-3.00001-8

Nascimento, D. M., Nunes, Y. L., Figueirêdo, M. C. B., De Azeredo, H. M. C., Aouada, F. A., Feitosa, J. P. A., et al. (2018). Nanocellulose Nanocomposite Hydrogels: Technological and Environmental Issues. Green. Chem. 20, 2428-2448. doi:10.1039/c8gc00205c

Nechyporchuk, O., Belgacem, M. N., and Bras, J. (2016). Production of Cellulose Nanofibrils: A Review of Recent Advances. Ind. Crops Prod. 93, 2-25. doi:10.1016/j.indcrop.2016.02.016

Niamsap, T., Lam, N. T., and Sukyai, P. (2019). Production of HydroxyapatiteBacterial Nanocellulose Scaffold with Assist of Cellulose Nanocrystals. Carbohydr. Polym. 205, 159-166. doi:10.1016/j.carbpol.2018.10.034

Nimbalkar, S., Dhatrak, P., Gherde, C., and Joshi, S. (2021). A Review Article on Factors Affecting Bone Loss in Dental Implants. Mater. Today Proc. 43, 970-976. doi:10.1016/j.matpr.2020.07.428

Nimeskern, L., Martínez Ávila, H., Sundberg, J., Gatenholm, P., Müller, R., and Stok, K. S. (2013). Mechanical Evaluation of Bacterial Nanocellulose as an Implant Material for Ear Cartilage Replacement. J. Mech. Behav. Biomed. Mater. 22, 12-21. doi:10.1016/j.jmbbm.2013.03.005

Olyveira, G. M., Valido, D. P., Costa, L. M. M., Gois, P. B. P., Xavier Filho, L., and Basmaji, P. (2011). First Otoliths/Collagen/Bacterial Cellulose Nanocomposites as a Potential Scaffold for Bone Tissue Regeneration. Jbnb 02, 239-243. doi:10.4236/jbnb.2011.23030

Ostadhossein, F., Mahmoudi, N., Morales-Cid, G., Tamjid, E., Navas-Martos, F., Soriano-Cuadrado, B., et al. (2015). Development of Chitosan/bacterial Cellulose Composite Films Containing Nanodiamonds as a Potential Flexible Platform for Wound Dressing. Materials 8, 6401-6418. doi:10.3390/ ma8095309

Pääkkö, M., Ankerfors, M., Kosonen, H., Nykänen, A., Ahola, S., Österberg, M., et al. (2007). Enzymatic Hydrolysis Combined with Mechanical Shearing and High-Pressure Homogenization for Nanoscale Cellulose Fibrils and strong Gels. Biomacromolecules 8, 1934-1941. doi:10.1021/bm061215p 
Pakzad, A., Simonsen, J., and Yassar, R. S. (2012). Gradient of Nanomechanical Properties in the Interphase of Cellulose Nanocrystal Composites. Composites Sci. Technology 72, 314-319. doi:10.1016/j.compscitech.2011.11.020

Palaganas, N. B., Mangadlao, J. D., de Leon, A. C. C., Palaganas, J. O., Pangilinan, K. D., Lee, Y. J., et al. (2017). 3D Printing of Photocurable Cellulose Nanocrystal Composite for Fabrication of Complex Architectures via Stereolithography. ACS Appl. Mater. Inter. 9, 34314-34324. doi:10.1021/ACSAMI.7B09223

Patchan, M., Graham, J. L., Xia, Z., Maranchi, J. P., Mccally, R., Schein, O., et al. (2013). Synthesis and Properties of Regenerated Cellulose-Based Hydrogels with High Strength and Transparency for Potential Use as an Ocular Bandage. Mater. Sci. Eng. C 33, 3069-3076. doi:10.1016/j.msec.2013.03.037

Perotti, G. F., Barud, H. S., Messaddeq, Y., Ribeiro, S. J. L., and Constantino, V. R. L. (2011). Bacterial Cellulose-Laponite clay Nanocomposites. Polymer 52, 157-163. doi:10.1016/j.polymer.2010.10.062

Phogat, K., Kanwar, S., Nayak, D., Mathur, N., Ghosh, S. B., and BandyopadhyayGhosh, S. (2020). Nano-enabled Poly(vinyl Alcohol) Based Injectable Bionanocomposite Hydrogel Scaffolds. J. Appl. Polym. Sci. 137, 48789. doi:10.1002/ APP.48789

Plackett, D., Letchford, K., Jackson, J., and Burt, H. (2014). A Review of Nanocellulose as a Novel Vehicle for Drug Delivery, Pulp Pap. Res. J., 29. 105-118. doi:10.3183/nppri-2014-29-01-p105-118

Poonguzhali, R., Khaleel Basha, S., and Sugantha Kumari, V. (2018). Novel Asymmetric chitosan/PVP/nanocellulose Wound Dressing: In Vitro and In Vivo Evaluation. Int. J. Biol. Macromolecules 112, 1300-1309. doi:10.1016/ j.ijbiomac.2018.02.073

Qiu, Y., Qiu, L., Cui, J., and Wei, Q. (2016). Bacterial Cellulose and Bacterial Cellulose-Vaccarin Membranes for Wound Healing. Mater. Sci. Eng. C 59, 303-309. doi:10.1016/j.msec.2015.10.016

Ramani, D., and Sastry, T. P. (2014). Bacterial Cellulose-Reinforced Hydroxyapatite Functionalized Graphene Oxide: A Potential Osteoinductive Composite. Cellulose 21, 3585-3595. doi:10.1007/s10570-014-0313-4

Recouvreux, D. O. S., Rambo, C. R., Berti, F. V., Carminatti, C. A., Antônio, R. V., and Porto, L. M. (2011). Novel Three-Dimensional Cocoon-like Hydrogels for Soft Tissue Regeneration. Mater. Sci. Eng. C 31, 151-157. doi:10.1016/ j.msec.2010.08.004

Ribeiro, L. N. M., Alcântara, A. C. S., Darder, M., Aranda, P., Herrmann, P. S. P., Araújo-Moreira, F. M., et al. (2014). Bionanocomposites Containing Magnetic Graphite as Potential Systems for Drug Delivery. Int. J. Pharmaceutics 477, 553-563. doi:10.1016/J.IJPHARM.2014.10.033

Sadasivuni, K. K., Kafy, A., Zhai, L., Ko, H.-U., Mun, S., and Kim, J. (2015). Transparent and Flexible Cellulose Nanocrystal/reduced Graphene Oxide Film for Proximity Sensing. Small 11, 994-1002. doi:10.1002/smll.201402109

Sai, H., Xing, L., Xiang, J., Cui, L., Jiao, J., Zhao, C., et al. (2013). Flexible Aerogels Based on an Interpenetrating Network of Bacterial Cellulose and Silica by a Non-supercritical Drying Process. J. Mater. Chem. A. 1, 7963. doi:10.1039/ c3ta11198a

Saito, T., Kimura, S., Nishiyama, Y., and Isogai, A. (2007). Cellulose Nanofibers Prepared by TEMPO-Mediated Oxidation of Native Cellulose. Biomacromolecules 8, 2485-2491. doi:10.1021/bm0703970

Sajjad, W., He, F., Ullah, M. W., Ikram, M., Shah, S. M., Khan, R., et al. (2020). Fabrication of Bacterial Cellulose-Curcumin Nanocomposite as a Novel Dressing for Partial Thickness Skin Burn. Front. Bioeng. Biotechnol. 8, 553037. doi:10.3389/fbioe.2020.553037

Sajjad, W., Khan, T., Ul-islam, M., Khan, R., Hussain, Z., Khalid, A., et al. (2019). Development of Modified Montmorillonite-Bacterial Cellulose Nanocomposites as a Novel Substitute for Burn Skin and Tissue Regeneration. Carbohydr. Polym. 206, 548-556. doi:10.1016/j.carbpol.2018.11.023

Saska, S., Barud, H. S., Gaspar, A. M. M., Marchetto, R., Ribeiro, S. J. L., and Messaddeq, Y. (2011). Bacterial Cellulose-Hydroxyapatite Nanocomposites for Bone Regeneration. Int. J. Biomater. 2011, 1-8. doi:10.1155/2011/175362

Saska, S., Teixeira, L. N., Tambasco De Oliveira, P., Minarelli Gaspar, A. M., Lima Ribeiro, S. J., Messaddeq, Y., et al. (2012). Bacterial Cellulose-Collagen Nanocomposite for Bone Tissue Engineering. J. Mater. Chem. 22, 22102. doi:10.1039/c2jm33762b

Satyamurthy, P., Jain, P., Balasubramanya, R. H., and Vigneshwaran, N. (2011). Preparation and Characterization of Cellulose Nanowhiskers from Cotton Fibres by Controlled Microbial Hydrolysis. Carbohydr. Polym. 83, 122-129. doi:10.1016/j.carbpol.2010.07.029
Shah, N., Ul-Islam, M., Khattak, W. A., and Park, J. K. (2013). Overview of Bacterial Cellulose Composites: A Multipurpose Advanced Material. Carbohydr. Polym. 98, 1585-1598. doi:10.1016/j.carbpol.2013.08.018

Shi, S., Chen, S., Zhang, X., Shen, W., Li, X., Hu, W., et al. (2009). Biomimetic Mineralization Synthesis of Calcium-Deficient Carbonate-Containing Hydroxyapatite in a Three-Dimensional Network of Bacterial Cellulose. J. Chem. Technol. Biotechnol. 84, 285-290. doi:10.1002/jctb.2037

Shi, Z., Gao, X., Ullah, M. W., Li, S., Wang, Q., and Yang, G. (2016). Electroconductive Natural Polymer-Based Hydrogels. Biomaterials 111, 40-54. doi:10.1016/j.biomaterials.2016.09.020

Shoda, M., and Sugano, Y. (2005). Recent Advances in Bacterial Cellulose Production. Biotechnol. Bioproc. Eng. 10, 1-8. doi:10.1007/bf02931175

Si, H., Luo, H., Xiong, G., Yang, Z., Raman, S. R., Guo, R., et al. (2014). One-step In Situ Biosynthesis of Graphene Oxide-Bacterial Cellulose Nanocomposite Hydrogels. Macromol. Rapid Commun. 35, 1706-1711. doi:10.1002/ marc.201400239

Stoica-Guzun, A., Stroescu, M., Jinga, S. I., Jipa, I. M., and Dobre, T. (2013). Microwave Assisted Synthesis of Bacterial Cellulose-Calcium Carbonate Composites. Ind. Crops Prod. 50, 414-422. doi:10.1016/j.indcrop.2013.07.063

Stoica-Guzun, A., Stroescu, M., Jinga, S., Jipa, I., Dobre, T., and Dobre, L. (2012). Ultrasound Influence upon Calcium Carbonate Precipitation on Bacterial Cellulose Membranes. Ultrason. Sonochem. 19, 909-915. doi:10.1016/ j.ultsonch.2011.12.002

Subhedar, A., Bhadauria, S., Ahankari, S., and Kargarzadeh, H. (2021). Nanocellulose in Biomedical and Biosensing Applications: A Review. Int. J. Biol. Macromolecules 166, 587-600. doi:10.1016/j.ijbiomac.2020.10.217

Sultan, S., Siqueira, G., Zimmermann, T., and Mathew, A. P. (2017). 3D Printing of Nano-Cellulosic Biomaterials for Medical Applications. Curr. Opin. Biomed. Eng. 2, 29-34. doi:10.1016/j.cobme.2017.06.002

Sultana, T., Van Hai, H., Abueva, C., Kang, H. J., Lee, S.-Y., and Lee, B.-T. (2019). TEMPO Oxidized Nano-Cellulose Containing Thermo-Responsive Injectable Hydrogel for post-surgical Peritoneal Tissue Adhesion Prevention. Mater. Sci. Eng. C 102, 12-21. doi:10.1016/J.MSEC.2019.03.110

Supramaniam, J., Adnan, R., Mohd Kaus, N. H., and Bushra, R. (2018). Magnetic Nanocellulose Alginate Hydrogel Beads as Potential Drug Delivery System. Int. J. Biol. Macromolecules 118, 640-648. doi:10.1016/ j.ijbiomac.2018.06.043

Tazi, N., Zhang, Z., Messaddeq, Y., Almeida-Lopes, L., Zanardi, L. M., Levinson, D., et al. (2012). Hydroxyapatite Bioactivated Bacterial Cellulose Promotes Osteoblast Growth and the Formation of Bone Nodules. AMB Expr. 2. doi:10.1186/2191-0855-2-61

Toro, R. G., Adel, A. M., de Caro, T., Federici, F., Cerri, L., Bolli, E., et al. (2021). Evaluation of Long-Lasting Antibacterial Properties and Cytotoxic Behavior of Functionalized Silver-Nanocellulose Composite. Materials 14, 4198. doi:10.3390/MA14154198

Trache, D., Hussin, M. H., Haafiz, M. K. M., and Thakur, V. K. (2017). Recent Progress in Cellulose Nanocrystals: Sources and Production. Nanoscale 9, 1763-1786. doi:10.1039/c6nr09494e

Tuerxun, D., Pulingam, T., Nordin, N. I., Chen, Y. W., Kamaldin, J. B., Julkapli, N. B. M., et al. (2019). Synthesis, Characterization and Cytotoxicity Studies of Nanocrystalline Cellulose from the Production Waste of Rubber-wood and Kenaf-Bast Fibers. Eur. Polym. J. 116, 352-360. doi:10.1016/ J.EURPOLYMJ.2019.04.021

Tummala, T., Lopes, L., Mihranyan, A., and Ferraz, F. (2019). Biocompatibility of Nanocellulose-Reinforced PVA Hydrogel with Human Corneal Epithelial Cells for Ophthalmic Applications. Jfb 10, 35. doi:10.3390/JFB10030035

Ul-Islam, M., Ahmad, F., Fatima, A., Shah, N., Yasir, S., Ahmad, M. W., et al. (2021). Ex Situ Synthesis and Characterization of High Strength Multipurpose Bacterial Cellulose-Aloe Vera Hydrogels. Front. Bioeng. Biotechnol. 9. doi:10.3389/fbioe.2021.601988

Ul-Islam, M., Khan, S., Ullah, M. W., and Park, J. K. (2019a). Comparative Study of Plant and Bacterial Cellulose Pellicles Regenerated from Dissolved States. Int. J. Biol. Macromolecules 137, 247-252. doi:10.1016/ j.ijbiomac.2019.06.232

Ul-Islam, M., Khan, T., Khattak, W. A., and Park, J. K. (2013). Bacterial CelluloseMMTs Nanoreinforced Composite Films: Novel Wound Dressing Material with Antibacterial Properties. Cellulose 20, 589-596. doi:10.1007/s10570-0129849-3 
Ul-Islam, M., Khan, T., and Park, J. K. (2012). Water Holding and Release Properties of Bacterial Cellulose Obtained by In Situ and Ex Situ Modification. Carbohydr. Polym. 88, 596-603. doi:10.1016/j.carbpol.2012.01.006

Ul-Islam, M., Khattak, W. A., Ullah, M. W., Khan, S., and Park, J. K. (2014). Synthesis of Regenerated Bacterial Cellulose-Zinc Oxide Nanocomposite Films for Biomedical Applications. Cellulose 21, 433-447. doi:10.1007/s10570-0130109-y

Ul-Islam, M., Subhan, F., Islam, S. U., Khan, S., Shah, N., Manan, S., et al. (2019b). Development of Three-Dimensional Bacterial Cellulose/chitosan Scaffolds: Analysis of Cell-Scaffold Interaction for Potential Application in the Diagnosis of Ovarian Cancer. Int. J. Biol. Macromolecules 137, 1050-1059. doi:10.1016/j.jibiomac.2019.07.050

Ullah, I., Gloria, A., Zhang, W., Ullah, M. W., Wu, B., Li, W., et al. (2019a). Synthesis and Characterization of Sintered $\mathrm{Sr} / \mathrm{Fe}$-Modified Hydroxyapatite Bioceramics for Bone Tissue Engineering Applications. ACS Biomater. Sci. Eng. 6, 375-388. doi:10.1021/acsbiomaterials.9b01666

Ullah, I., Zhang, W., Yang, L., Ullah, M. W., Atta, O. M., Khan, S., et al. (2020). Impact of Structural Features of $\mathrm{Sr} / \mathrm{Fe}$ Co-doped HAp on the Osteoblast Proliferation and Osteogenic Differentiation for its Application as a Bone Substitute. Mater. Sci. Eng. C 110, 110633. doi:10.1016/j.msec.2020.110633

Ullah, M. W., Manan, S., Kiprono, S. J., Ul-Islam, M., and Yang, G. (2019b). Synthesis, Structure, and Properties of Bacterial Cellulose, 81, 113. doi:10.1002/ 9783527807437.ch4

Ullah, M. W., Rojas, O. J., McCarthy, R. R., and Yang, G. (2021). Editorial: Nanocellulose: A Multipurpose Advanced Functional Material. Front. Bioeng. Biotechnol. 9, 681. doi:10.3389/FBIOE.2021.738779

Ullah, M. W., Ul Islam, M., Khan, S., Shah, N., and Park, J. K. (2017). Recent Advancements in Bioreactions of Cellular and Cell-free Systems: A Study of Bacterial Cellulose as a Model. Korean J. Chem. Eng. 34, 1591-1599. doi:10.1007/s11814-017-0121-2

Ullah, M. W., Ul-Islam, M., Khan, S., Kim, Y., Jang, J. H., and Park, J. K. (2016a). In Situ synthesis of a Bio-Cellulose/titanium Dioxide Nanocomposite by Using a Cell-free System. RSC Adv. 6, 22424-22435. doi:10.1039/c5ra26704h

Ullah, M. W., Ul-Islam, M., Khan, S., Kim, Y., and Park, J. K. (2015). Innovative Production of Bio-Cellulose Using a Cell-free System Derived from a Single Cell Line. Carbohydr. Polym. 132, 286-294. doi:10.1016/ j.carbpol.2015.06.037

Ullah, M. W., Ul-Islam, M., Khan, S., Kim, Y., and Park, J. K. (2016b). Structural and Physico-Mechanical Characterization of Bio-Cellulose Produced by a Cell-free System. Carbohydr. Polym. 136, 908-916. doi:10.1016/j.carbpol.2015.10.010

Vilela, C., Oliveira, H., Almeida, A., Silvestre, A. J. D., and Freire, C. S. R. (2019). Nanocellulose-based Antifungal Nanocomposites against the Polymorphic Fungus Candida Albicans. Carbohydr. Polym. 217, 207-216. doi:10.1016/ j.carbpol.2019.04.046

Wågberg, L., Decher, G., Norgren, M., Lindström, T., Ankerfors, M., and Axnäs, K. (2008). The Build-Up of Polyelectrolyte Multilayers of Microfibrillated Cellulose and Cationic Polyelectrolytes. Langmuir 24, 784-795. doi:10.1021/la702481v

Wan, Y. Z., Huang, Y., Yuan, C. D., Raman, S., Zhu, Y., Jiang, H. J., et al. (2007). Biomimetic Synthesis of Hydroxyapatite/bacterial Cellulose Nanocomposites for Biomedical Applications. Mater. Sci. Eng. C 27, 855-864. doi:10.1016/ j.msec.2006.10.002

Wang, D., Xu, Y., Li, Q., and Turng, L.-S. (2020a). Artificial Small-Diameter Blood Vessels: Materials, Fabrication, Surface Modification, Mechanical Properties, and Bioactive Functionalities. J. Mater. Chem. B 8, 1801-1822. doi:10.1039/ С9ТВ01849B

Wang, J., Gao, C., Zhang, Y., and Wan, Y. (2010a). Preparation and In Vitro Characterization of BC/PVA Hydrogel Composite for its Potential Use as Artificial Cornea Biomaterial. Mater. Sci. Eng. C 30, 214-218. doi:10.1016/ j.msec.2009.10.006

Wang, J., Wan, Y., Han, J., Lei, X., Yan, T., and Gao, C. (2011). Nanocomposite Prepared by Immobilising Gelatin and Hydroxyapatite on Bacterial Cellulose Nanofibres. Micro Nano Lett. 6, 133. doi:10.1049/mnl.2010.0209

Wang, L., Hu, S., Ullah, M. W., Li, X., Shi, Z., and Yang, G. (2020b). Enhanced Cell Proliferation by Electrical Stimulation Based on Electroactive Regenerated Bacterial Cellulose Hydrogels. Carbohydr. Polym. 249, 116829. doi:10.1016/ j.carbpol.2020.116829

Wang, L., Mao, L., Qi, F., Li, X., Wajid Ullah, M., Zhao, M., et al. (2021). Synergistic Effect of Highly Aligned Bacterial Cellulose/gelatin Membranes and Electrical
Stimulation on Directional Cell Migration for Accelerated Wound Healing. Chem. Eng. J. 424, 130563. doi:10.1016/j.cej.2021.130563

Wang, W., Li, H.-Y., Zhang, D.-W., Jiang, J., Cui, Y.-R., Qiu, S., et al. (2010b). Fabrication of Bienzymatic Glucose Biosensor Based on Novel Gold Nanoparticles-Bacteria Cellulose Nanofibers Nanocomposite. Electroanalysis 22, 2543-2550. doi:10.1002/elan.201000235

Wu, X. H., Wu, Z. Y., Qian, J., Yan, Y. G., Wei, J., Li, H., et al. (2015). Photocrosslinked Hierarchically Honeycomb-Patterned/macroporous Scaffolds of Calcium Phosphate Cement Promote MC3T3-E1 Cell Functions. RSC Adv. 5, 36007-36014. doi:10.1039/C5RA01332A

Xiong, R., Hu, K., Grant, A. M., Ma, R., Xu, W., Lu, C., et al. (2016). Ultrarobust Transparent Cellulose Nanocrystal-Graphene Membranes with High Electrical Conductivity. Adv. Mater. 28, 1501-1509. doi:10.1002/adma.201504438

Xu, Q, Ji, Y, Sun, Q, Fu, Y, Xu, Y, and Jin, L (2019). Fabrication of Cellulose Nanocrystal/Chitosan Hydrogel for Controlled Drug Release. Nanomater. 9, 253. doi:10.3390/NANO 9020253

Yang, J., Han, C.-R., Zhang, X.-M., Xu, F., and Sun, R.-C. (2014). Cellulose Nanocrystals Mechanical Reinforcement in Composite Hydrogels with Multiple Cross-Links: Correlations between Dissipation Properties and Deformation Mechanisms. Macromolecules 47, 4077-4086. doi:10.1021/MA500729Q

Yano, S., Maeda, H., Nakajima, M., Hagiwara, T., and Sawaguchi, T. (2008). Preparation and Mechanical Properties of Bacterial Cellulose Nanocomposites Loaded with Silica Nanoparticles. Cellulose 15, 111-120. doi:10.1007/s10570007-9152-x

Yuan, H., Chen, L., and Hong, F. F. (2020). A Biodegradable Antibacterial Nanocomposite Based on Oxidized Bacterial Nanocellulose for Rapid Hemostasis and Wound Healing. ACS Appl. Mater. Inter. 12, 3382-3392. doi:10.1021/acsami.9b17732

Yunessnia lehi, A., Shagholani, H., Ghorbani, M., Nikpay, A., Soleimani lashkenari, M., and Soltani, M. (2019). Chitosan Nanocapsule-Mounted Cellulose Nanofibrils as Nanoships for Smart Drug Delivery Systems and Treatment of Avian Trichomoniasis. J. Taiwan Inst. Chem. Eng. 95, 290-299. doi:10.1016/ J.JTICE.2018.07.014

Zang, S., Sun, Z., Liu, K., Wang, G., Zhang, R., Liu, B., et al. (2014). Ordered Manufactured Bacterial Cellulose as Biomaterial of Tissue Engineering. Mater. Lett. 128, 314-318. doi:10.1016/j.matlet.2014.04.183

Zang, S., Zhang, R., Chen, H., Lu, Y., Zhou, J., Chang, X., et al. (2015). Investigation on Artificial Blood Vessels Prepared from Bacterial Cellulose. Mater. Sci. Eng. C 46, 111-117. doi:10.1016/j.msec.2014.10.023

Zhang, X., Wang, C., Liao, M., Dai, L., Tang, Y., Zhang, H., et al. (2019). Aligned Electrospun Cellulose Scaffolds Coated with rhBMP-2 for Both In Vitro and In Vivo Bone Tissue Engineering. Carbohydr. Polym. 213, 27-38. doi:10.1016/ j.carbpol.2019.02.038

Zhijiang, C., and Guang, Y. (2011). Bacterial Cellulose/Collagen Composite: Characterization and First Evaluation of Cytocompatibility. Appl. Polym. 120, 2938-2944. doi:10.1002/app.33318

Zimmermann, K. A., LeBlanc, J. M., Sheets, K. T., Fox, R. W., and Gatenholm, P. (2011). Biomimetic Design of a Bacterial Cellulose/hydroxyapatite Nanocomposite for Bone Healing Applications. Mater. Sci. Eng. C 31, 43-49. doi:10.1016/J.MSEC.2009.10.007

Conflict of Interest: The authors declare that the research was conducted in the absence of any commercial or financial relationships that could be construed as a potential conflict of interest.

Publisher's Note: All claims expressed in this article are solely those of the authors and do not necessarily represent those of their affiliated organizations, or those of the publisher, the editors and the reviewers. Any product that may be evaluated in this article, or claim that may be made by its manufacturer, is not guaranteed or endorsed by the publisher.

Copyright $\odot 2021$ Wang, Bai, Tian, Xie, Duan, Lv and Tao. This is an open-access article distributed under the terms of the Creative Commons Attribution License (CC $B Y)$. The use, distribution or reproduction in other forums is permitted, provided the original author(s) and the copyright owner(s) are credited and that the original publication in this journal is cited, in accordance with accepted academic practice. No use, distribution or reproduction is permitted which does not comply with these terms. 